\title{
Characteristics and controls of variability in soil moisture and groundwater in a headwater catchment
}

\author{
H. K. McMillan and M. S. Srinivasan \\ National Institute of Water and Atmospheric Research, P.O. Box 8602, Christchurch, New Zealand \\ Correspondence to: H. K. McMillan (h.mcmillan@niwa.co.nz)
}

Received: 5 June 2014 - Published in Hydrol. Earth Syst. Sci. Discuss.: 11 August 2014

Revised: 29 January 2015 - Accepted: 21 March 2015 - Published: 17 April 2015

\begin{abstract}
Hydrological processes, including runoff generation, depend on the distribution of water in a catchment, which varies in space and time. This paper presents experimental results from a headwater research catchment in New Zealand, where we made distributed measurements of streamflow, soil moisture and groundwater levels, sampling across a range of aspects, hillslope positions, distances from stream and depths. Our aim was to assess the controls, types and implications of spatial and temporal variability in soil moisture and groundwater tables.

We found that temporal variability in soil moisture and water table is strongly controlled by the seasonal cycle in potential evapotranspiration, for both the mean and extremes of their distributions. Groundwater is a larger water storage component than soil moisture, and this general difference increases even more with increasing catchment wetness. The spatial standard deviation of both soil moisture and groundwater is larger in winter than in summer. It peaks during rainfall events due to partial saturation of the catchment, and also rises in spring as different locations dry out at different rates. The most important controls on spatial variability in storage are aspect and distance from the stream. South-facing and near-stream locations have higher water tables and showed soil moisture responses for more events. Typical hydrological models do not explicitly account for aspect, but our results suggest that it is an important factor in hillslope runoff generation.

Co-measurement of soil moisture and water table level allowed us to identify relationships between the two. Locations where water tables peaked closer to the surface had consistently wetter soils and higher water tables. These wetter sites were the same across seasons. However, patterns of strong
\end{abstract}

soil moisture responses to summer storms did not correspond to the wetter sites.

Total catchment spatial variability is composed of multiple variability sources, and the dominant type is sensitive to those stores that are close to a threshold such as field capacity or saturation. Therefore, we classified spatial variability as "summer mode" or "winter mode". In "summer mode", variability is controlled by shallow processes, e.g. interaction of water with soils and vegetation. In "winter mode", variability is controlled by deeper processes, e.g. groundwater movement and bypass flow. Double streamflow peaks observed during some events show the direct impact of groundwater variability on runoff generation. Our results suggest that emergent catchment behaviour depends on the combination of these multiple, time varying components of storage variability.

\section{Introduction}

Hydrological processes, including runoff generation, depend on the distribution of water in a catchment, in space and time. Understanding the distribution and its effects on hydrological processes is a prerequisite for identifying hydrological principles (Troch et al., 2008) and building hydrological models that produce "the right answers for the right reasons" (Kirchner, 2006). However, water stores and fluxes are typically characterised by high complexity and variability at all scales (e.g. Grayson et al., 2002; Zimmer et al., 2012). The high variability of soil water and groundwater has farreaching implications for hydrological measurement, prediction and modelling. Most measurements of soil moisture or groundwater are made at the point scale, and so high vari- 
ability makes it difficult and costly to estimate spatial average values. However, studies into controls on variability can give insights into the best monitoring locations and strategies to estimate spatial averages (e.g. Teuling et al., 2006, for soil moisture), and may allow us to identify sites that are likely to mirror the mean wetness conditions of the catchment (Grayson and Western, 1998).

Hydrological models simulate water fluxes integrated over some "model element" scale, so where variability exists below that scale, model fluxes will differ from point-scale measurements (Blöschl and Sivapalan, 1995; Western et al., 2002). This makes it difficult to compare model simulations against measured data. The same scale sensitivity affects climate models, which use land surface water content as a boundary condition (Seneviratne et al., 2010). In addition, the prevalence of high nonlinearity and thresholds in hydrological responses means that simple averaging of water content is not sufficient. For example, integrated drainage fluxes derived from soil moisture patterns with realistic variability and spatial organisation exceed those estimated from uniform soil moisture fields (Bronstert and Bardossy, 1999; Grayson and Bloschl, 2000). Model descriptions of relationships between mean soil moisture and drainage must therefore be altered to take account of soil moisture variability (e.g. Moore, 2007; Wood et al., 1992) and organisation (Lehmann et al., 2007), and may need to change seasonally as soil moisture variability changes (McMillan, 2012). Similarly, averaging of soil texture or water-holding properties should take spatial organisation into account. Threshold relationships between water content and runoff generation, which have been widely observed at the point scale, should be smoothed at the model element scale to reflect spatial variability (Kavetski et al., 2006). The critical point here is that multiple sources and characteristics of variability may exist in any catchment. To understand and model the emergent catchment-scale processes they create, we must understand how the individual components of variability interact and change with time.

A well-established strategy to improve our understanding of hydrological variability and processes is through the development of densely instrumented research catchments (Tetzlaff et al., 2008; Sidle, 2006; Warmerdam and Stricker, 2009). Such sites expose interrelations and patterns in hydrological variables, and allow us to test hypotheses on catchment function. In recent years, improved sensor and communication technologies have increased our ability to capture space and time variability in hydrological processes, storage and fluxes (Soulsby et al., 2008). While acknowledging the importance of breadth as well as depth in hydrological analysis (Gupta et al., 2014), intensively studied catchments remain a critical part of hydrological research.

In New Zealand, experiments in research catchments have uncovered the importance of vertical flow and the displacement mechanism for streamflow generation, using applied tracers (Woods et al., 2001; Mahurangi catchment) and isotope measurements (McGlynn et al., 2002; Maimai catch- ment). The subsequent incorporation of our revised process understanding into conceptual models of the catchments has emphasised the need to measure variability and dynamic response in groundwater as well as soil moisture (e.g. Graham and McDonnell, 2010; Fenicia et al., 2010). Groundwater dynamics and subsurface flow pathways are a key control on runoff generation and flow dynamics in a variety of different catchments (Onda et al., 2001; Soulsby et al., 2007), with strong evidence coming from hydrochemical analysis of streamwater. The hydrology of the riparian zone may be particularly sensitive to groundwater connections (Vidon and Hill, 2004). While previous NZ catchment studies have measured groundwater response in a limited number of locations (Bidwell et al., 2008) or without simultaneous surface water measurements (Gabrielli et al., 2012), a joint data set of spatio-temporal surface and groundwater measurements did not previously exist in New Zealand.

The results presented in this paper, from a research catchment in the headwaters of Waipara catchment, provide data to characterise and test hypotheses on variability and model representation of integrated surface water-groundwater systems. Such models are in high demand for management applications, as local governments must set allocation limits and manage supply under increasing demands for water. Although surface water and groundwater systems have, historically, often been managed independently, there is now recognition that extractive use from either source impacts the whole system (Lowry et al., 2003).

The aims of this paper are therefore (1) to present initial experimental data of surface water and groundwater responses from a research catchment in the alpine foothills of New Zealand and (2) to assess the types of spatial and temporal variability in soil moisture and groundwater in this headwater catchment, the factors that control the variability, and the implications for modelling.

\subsection{Soil moisture variability}

New Zealand has some well-known experimental catchments, which offer information on causes and effects of hydrological variability, focusing on the soil zone. In the Mahurangi catchment in Northland, Wilson et al. (2004) compared the variability of gridded soil moisture measurements in time vs. in space. They found that temporal variability was approximately 5 times greater than spatial variability. Temporal variability was highly predictable, and explained by seasonality, whereas spatial variability was less easily predictable and only partly explained by terrain indices. In the same catchment, Wilson et al. (2003) compared variability of soil moisture at $0-6 \mathrm{~cm}$ depth vs. $30 \mathrm{~cm}$ depth, and found differences in distribution and low correlations between the two depths. At Maimai catchment in Westland, nested arrays of tensiometers were used to estimate variability in the depth to water table. High variability was found within nests (plot 
Table 1. Examples of controls on soil moisture distribution found in international studies.

\begin{tabular}{lll}
\hline Reference & Control & Relationship \\
\hline Brocca et al. (2007) & Upslope area & $\begin{array}{l}\text { Positive spatial correlation between soil } \\
\text { moisture and ln(upslope area) at 14 sampling } \\
\text { times. }\end{array}$ \\
\hline Qiu et al. (2001) & $\begin{array}{l}\text { Land use and } \\
\text { topography descriptors } \\
\text { including slope, aspect } \\
\text { and elevation }\end{array}$ & $\begin{array}{l}\text { Statistically significant spatial correlation } \\
\text { between mean soil moisture and classifications } \\
\text { of land use (higher soil moisture for crops than } \\
\text { forest), aspect (higher soil moisture for the northern } \\
\text { aspect) and slope position (higher soil moisture } \\
\text { for downslope locations). }\end{array}$ \\
\hline Kim et al. (2007) & Topographic position & $\begin{array}{l}\text { Topographic zones (upper, buffer and flow } \\
\text { path zones) defined by contributing area and } \\
\text { distance to flow path. Qualitative differences in } \\
\text { soil moisture dynamics found between zones. }\end{array}$ \\
\hline Penna et al. (2009) & $\begin{array}{l}\text { Slope, topographic } \\
\text { index }\end{array}$ & $\begin{array}{l}\text { At five sites and three depths, Pearson's correlation } \\
\text { typically positive between soil moisture and } \\
\text { topographic wetness index, always negative } \\
\text { between soil moisture and slope. }\end{array}$ \\
\hline Odoux (1997) & $\begin{array}{l}\text { Significant positive Spearman correlation } \\
\text { between soil moisture and topographic } \\
\text { wetness index. }\end{array}$ \\
\hline Nyberg (1996) & Topographic index & $\begin{array}{l}\text { Fitted negative exponential relationship } \\
\text { between soil moisture and height above the } \\
\text { nearest drainage. }\end{array}$ \\
\hline
\end{tabular}

scale) and between nests (hillslope scale) (McDonnell, 1990; Freer et al., 2004).

Some characteristics of the New Zealand climate and landscape may result in locally important controls on variability. Aspect is important in New Zealand hill country, due to high radiation and prevailing wind direction. Typically, Penman PET is $35-50 \%$ greater on north-facing than southfacing slopes (Jackson, 1967; Bretherton et al., 2010), or more for sites exposed to the prevailing WNW wind (Lambert and Roberts, 1976). At one site, these differences translated into mean soil moisture differences of $10 \%$ (Bretherton et al., 2010). In a similar environment to the catchment described in this paper (i.e. the eastern foothills of the Southern Alps, greywacke geology), aspect-induced microclimate differences were found to promote physical and chemical soil differences, with stronger leaching and weathering on southfacing slopes (Eger and Hewitt, 2008).

Controls on soil moisture are varied and may affect soil moisture mean (in either space or time), distribution (Teuling et al., 2005) and dynamics such as recession, stability or recharge rate (Kim et al., 2007). Examples from previous (international) studies are given in Table 1. Controls can also interact, such as soil type and topography (Crave and GascuelOdoux, 1997). Even though new technologies are available to measure soil moisture and its variation at larger scales, in- cluding remote microwave sensing (Njoku et al., 2002) and electrical resistivity tomography (Michot et al., 2003), there is still no accurate way of predicting soil moisture patterns, with studies based on topography typically predicting less than $50 \%$ of the spatial variation (see the review by Wilson et al., 2004).

High variability in soil moisture has many implications for hydrological process understanding and modelling. There is a large body of work investigating causes of low vs. high variability, without attempting to predict exact spatial or temporal patterns, often using geostatistical methods to quantify the magnitude and the scales of variation (e.g. Western et al., 1998; Brocca et al., 2007). Causes of high variability have been found to be dry conditions (Brocca et al., 2007), midwetness conditions (Ryu and Famiglietti, 2005; Rosenbaum et al., 2012), wet or dry conditions conditional on climate, soil and vegetation types (Teuling and Troch, 2005; Teuling et al., 2007), increasing scale (Famiglietti et al., 2008; Entin et al., 2000), aspects of land use and topography (Qiu et al., 2001), groundwater influence, and contrasts between groundwater influenced/uninfluenced areas (Rosenbaum et al., 2012). 


\subsection{Groundwater variability}

Studies of variability in groundwater dynamics are less common, reflecting the greater difficulty and expense in measuring groundwater levels, but a wide range of controls on groundwater levels have been identified. Detty and McGuire (2010a) considered surface topography controls, by dividing the landscape into landform units, e.g. footslopes, planar backslopes, or convex shoulders. They found statistical differences in metrics of water table hydrograph shape between different landform units. The water table response increased in duration and magnitude from shoulders to footslopes, but was most sustained on backslopes. The responses also differed between the growing and dormant seasons. Anderson and Burt (1978) showed that topography can control matric potential and downslope flow: at their field site, hillslope "hollows" had specific discharge an order of magnitude higher than hillslope spurs. Fujimoto et al. (2008) found that topography interacts with storm size to control subsurface processes. For small storms, a concave hillslope stored more water than a planar slope and produced less runoff, whereas for larger storms, transient groundwater in the concave slope caused greater expansion of the saturated area than in the planar slope, and correspondingly greater runoff. Bachmair et al. (2012) drilled 9 transects, each of 10 shallow wells $(<2 \mathrm{~m}$ deep) to study the effect of land use and landscape position on variability in groundwater dynamics. They found that patterns of groundwater response in winter reflected expansion of saturated areas at the base of the hillslope, whereas in summer, groundwater response was controlled by transient preferential flow networks and was highly spatially variable. The wells with the strongest response also varied between events. The relationship between topography and subsurface flow dynamics has been demonstrated theoretically (Harman and Sivapalan, 2009), although bedrock topography may be more important than surface topography (Freer et al., 2002; Graham et al., 2010; Tromp-van Meerveld and McDonnell, 2006a, b).

Other factors may also control the variability in groundwater responses, such as variability in recharge. Gleeson et al. (2009) tracked snowmelt recharge to groundwater using 15 bedrock wells in a humid Canadian catchment with flat topography. In addition to widespread slow recharge, they found fast, localised recharge in areas with both thin soils and fractured bedrock. Riparian soils can form a fast conduit to groundwater, where a higher fraction of gravel leads to hydraulic conductivities an order of magnitude higher than the hillslope soils (Detty and McGuire, 2010b).

Characteristics of the groundwater aquifers are also important. Winter et al. (2008) and Tiedeman et al. (1998) monitored 31 bedrock wells and found water table gradients caused by different geological units within a catchment. Even in headwater catchments, variability in groundwater dynamics has been found due to multiple underlying aquifers (Kosugi et al., 2008, 2011). In Plynlimon catchment in Wales, Haria and Shand (2004) found that groundwater at $1.5,10$ and $30 \mathrm{~m}$ depth was not hydraulically connected, and was chemically stratified, with distinct $\mathrm{pH}$, electrical conductivity and redox characteristics. Different groundwater pathways to the stream could therefore be identified, including discharge from fractured bedrock, and upwelling into the soil zone causing rapid lateral flow.

\subsection{Soil moisture-groundwater interactions and variability}

The division between stored water that is considered soil moisture or groundwater is not well defined. Soil moisture is typically measured as volumetric water content at a specific depth in the unsaturated zone, although soil moisture sensors can be subsumed by groundwater. Here, we use groundwater level synonymously with water table, referring to saturated subsurface layers, which may be above or below any soilbedrock interface. Piezometers or shallow wells to measure groundwater level can be screened along their whole length (as in our study) or at specific depths if multiple perched or confined layers are suspected. Where the geology includes fractured rock or buried lenses of gravels, groundwater levels may be highly heterogeneous.

There are many processes by which soil moisture and groundwater interact. As soil water drains downwards, layers of low hydraulic conductivity may create perched water tables. Such layers include clay pans (Parlange et al., 1989) and the soil-bedrock interface (Tromp-van Meerveld and McDonnell, 2006a). Macropores provide a fast route for groundwater recharge (Beven and Germann, 2013). They may allow water to bypass confining layers or to flow quickly along them (e.g. lateral preferential flow along the bedrock interface found by Graham et al., 2010). If groundwater rises into upper soil layers, large increases in soil matrix porosity or macropores may "cap" water table levels, as additional water is quickly transported to the stream (Haught and Meerveld, 2011). Lana-Renault et al. (2014) found in a Mediterranean catchment that patterns of near-surface saturation and transient water tables were affected not only by topography, but also by soil properties and previous agricultural land use. The riparian zone facilitates mixing between soil water and groundwater, and tracers, temperature, electrical conductivity, flow gauging and head differences may all be used to quantify the interactions (Unland et al., 2013). Using modelling and tracer data, Binley et al. (2013) found that in a $200 \mathrm{~m}$ river reach the upper section was connected to regional groundwater, but lower section inflows were from local lateral and down-river flow paths.

Interactions between soil moisture and groundwater provide possible explanations for relationships between the two. Results from three Nordic catchments showed a consistent negative correlation between soil moisture content and depth to water table, so that soil moisture distributions could be described as a function of depth to water table (Beldring et 

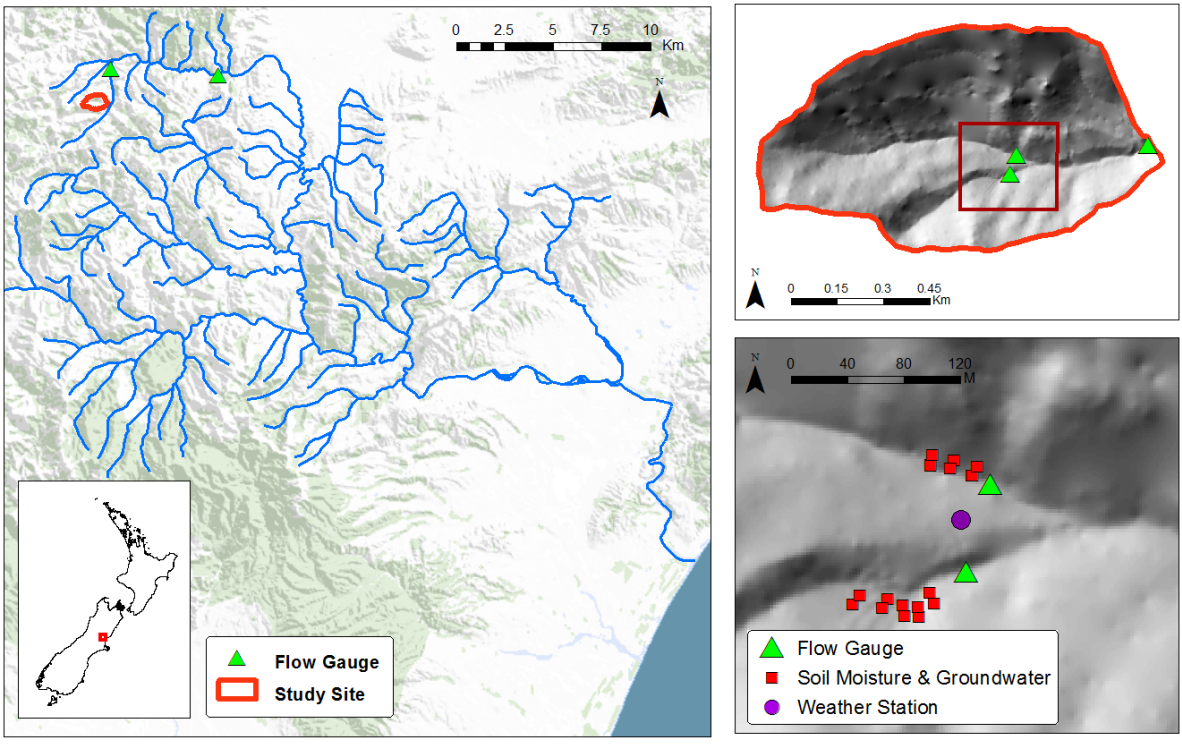

Figure 1. Catchment location and instrumentation.

Table 2. Fractions of stones, sand, clay for typical spur and footslope soils at $0-30 \mathrm{~cm}$ depth. Sand and clay values exclude the coarse fraction.

\begin{tabular}{lrrc}
\hline & Stones & Sand & Clay \\
\hline Spurs & $30-80 \%$ & $10-50 \%$ & $10-25 \%$ \\
Footslopes & $5-20 \%$ & $5-40 \%$ & $20-35 \%$ \\
\hline
\end{tabular}

al., 1999). Kaplan and Munoz-Carpena (2011) studied soil moisture regimes in a coastal floodplain forest in Florida, and showed that groundwater and standing surface water elevations were successful predictors of soil moisture using dynamic factor analysis and regression models. Model-based studies demonstrate how capillary rise can lead to dependencies between groundwater level and soil moisture. Kim et al. (1999) used a hillslope model to show how gravitydriven downhill groundwater flow creates downslope zones with high water tables. In those areas, capillary rise keeps soil moisture content and evaporation rates high. Similarly, the model developed by Chen and $\mathrm{Hu}$ (2004) showed that soil moisture in the upper $1 \mathrm{~m}$ of soil was $21 \%$ higher when exchange between soil moisture and groundwater was included; they inferred that groundwater variability may drive soil moisture variability.

\section{Study area}

The Langs Gully catchment is located in the South Island of New Zealand, in the headwaters of the Waipara River that has its source in the foothills of the Southern Alps before emptying onto alluvial plains (Fig. 1). Langs Gully is typical
Table 3. Fractions of stones and sand for typical footslope soils at $0-30$ and $30-60 \mathrm{~cm}$ depth.

\begin{tabular}{lrrc}
\hline & Stones & Sand & Clay \\
\hline $0-30 \mathrm{~cm}$ & $5-20 \%$ & $5-40 \%$ & $20-35 \%$ \\
$30-60 \mathrm{~cm}$ & $35-80 \%$ & $10-40 \%$ & $20-35 \%$ \\
\hline
\end{tabular}

of the Canterbury foothills landscape. This area is the source of many rivers and aquifers that provide essential irrigation water for the drier and intensively farmed plains; however, the hydrology of the area is poorly understood.

The $0.7 \mathrm{~km}^{2}$ catchment ranges from 500 to $750 \mathrm{~m}$ in elevation, and is drained by two tributaries. Annual precipitation ranges from 500 to $1100 \mathrm{~mm} \mathrm{yr}^{-1}$, with a mean of $943 \mathrm{~mm} \mathrm{yr}^{-1}$. In winter the catchment has relatively frequent frosts and occasional snow. The land cover is grazed pasture for sheep and beef cattle farming, with a partial cover of sparse Matagouri (Discaria toumatou) shrub. The geology is greywacke, a hard sandstone with poorly sorted angular grains set in a compact matrix. Soils are shallow gravelly silt loams derived from the underlying greywacke, and were classified as midslope, footslope or spur (Fig. 2), based on expert knowledge and the S-MAP New Zealand soils map (Lilburne et al., 2004), which uses soil survey data, and topography-based interpolation (Schmidt and Hewitt, 2004). The mapping also provided estimates of fractions of stone, sand and clay for each soil type. Fractions of stone and sand decreased from spurs to footslopes, while fractions of clay increased (Table 2). Stone and sand fractions increase with depth for all soils (e.g. the footslope constituents shown in Table 3). During installation of soil moisture sen- 

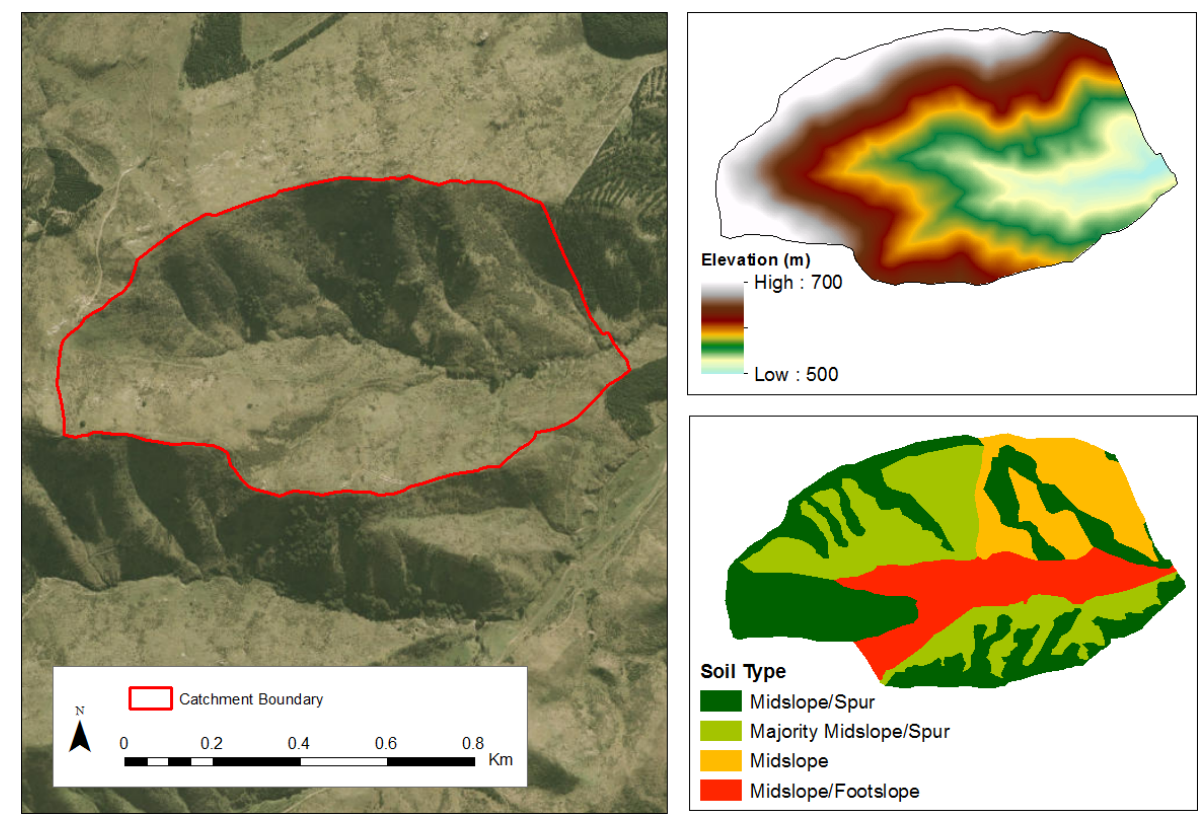

Figure 2. Catchment aerial photo, topography and soils.

sors (Sect. 3.2), we found distinct gravel-rich layers within the soil profile at 6 out of 16 locations.

\section{Materials and methods}

The aim of our experimental design was to study the temporal and spatial variability in water storage within the catchment. We installed sensors to measure rainfall, climate variables, streamflow, soil moisture and depth of shallow groundwater. Our aim was to take measurements at locations representing the variability of hydrological conditions within the catchment, and where possible to co-locate sensors in order to understand relationships between different water stores. We selected two hillslopes for detailed measurements of soil moisture and shallow groundwater, with different aspects (northern and southern) (Fig. 1).

To support the sensor data, we took aerial photos and used GPS mapping to create a digital elevation model of the catchment (Fig. 2). Aerial photos were only taken on the slope above the north-facing sites; GPS point spacing was also closer in this area. A soils map was created using a combination of nationally available data and a field survey (Fig. 2).

\subsection{Climate and streamflow monitoring}

A compact weather station was located centrally within the catchment (Fig. 1). It uses a Vaisala WXT520 weather transmitter, which measures wind speed and direction, air temperature, barometric pressure and relative humidity. A LiCOR LI200 pyranometer measures solar radiation. Rainfall was measured using an OTA OSK15180T $0.2 \mathrm{~mm}$ resolution tip- ping bucket gauge. All weather measurements were at $5 \mathrm{~min}$ intervals.

Streamflow was measured at three locations within the catchment (Fig. 1), all at $5 \mathrm{~min}$ intervals. Only data from the downstream gauge, a v-notch weir, were used in this paper. Periodical manual gaugings were used to confirm the theoretical weir flow rates.

\subsection{Soil moisture and shallow groundwater monitoring}

Soil moisture and water table level were monitored by 16 instrument stations. The stations are divided into two groups: 10 on the north-facing slope, and 6 on the south-facing slope.

Our typical measurement site included an Acclima TDT soil moisture sensor at $30 \mathrm{~cm}$ (base of the root zone) and $60 \mathrm{~cm}$, which were used with factory calibration as recommended by the manufacturer (Acclima, 2014). The sites also included a well drilled to a fixed depth of $1.5 \mathrm{~m}$ (except where a high fraction of stones prevented the full depth being reached) equipped with a Solinst levelogger to measure water level. The wells were sealed for the top $0.5 \mathrm{~m}$ to prevent ingress of surface water, with open screening below this. On each hillslope, we centred the sites around a shallow gully surface feature, with sites in the centre of the gully and on each bank. The sites were designed in two rows, at $10 \mathrm{~m}$ and $20 \mathrm{~m}$ from the stream centreline (Fig. 1). In this way, we aimed to sample across multiple variables of aspect, slope position and distance from stream. All sensors recorded at $5 \mathrm{~min}$ intervals, which were typically aggregated to $15 \mathrm{~min}$ before further analysis. 

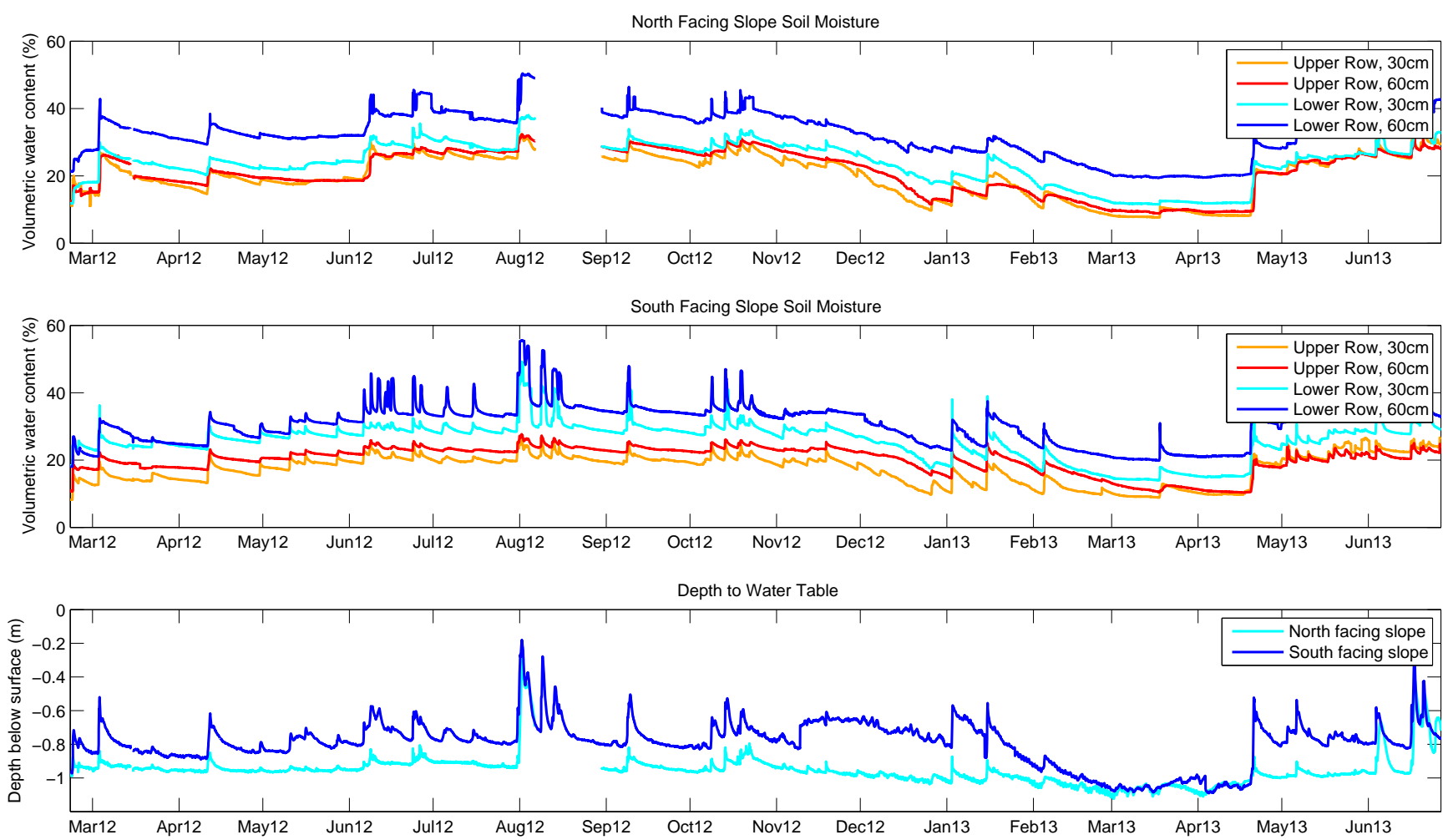

Figure 3. Time series of average soil moisture and groundwater level for the complete study period.

\subsection{Telemetry}

Each station aggregates sensor data and discards unneeded data. Each group is associated with a "master" station that polls the individual stations every $5 \mathrm{~min}$ for their sensor data. The master station comprises a Unidata Satellite NRT datalogger and a proprietary short-haul radio interface. The data received by the master station are stored temporarily in the logger until they can be relayed to a central database via satellite. Data in the central database are available to end users via internet and e-mail. To conserve power in the solarrecharged batteries, the sensors and radio system are only powered up to respond to data requests.

\subsection{Study period}

The data used in this paper were collected between March 2012 and July 2013 (Fig. 3). Climate and flow data are available for 14 months prior to this date. The largest rainfall event in the study period occurred in August 2012, which brought $80.6 \mathrm{~mm}$ of rainfall in 2 days, approximately a 1-in-2 year rainfall event when compared against the 62 year daily rainfall record from Melrose station, $2.0 \mathrm{~km}$ from the catchment. The 2012-2013 summer was unusually dry in many parts of New Zealand but, at Melrose, the summer months December/January/February recorded a rainfall to- tal of $196 \mathrm{~mm}$, only marginally below the long-term average of $210 \mathrm{~mm}$.

Some data gaps occurred during the study period, with short outages due to sensor or battery failure. A long outage occurred in the aftermath of the storm event in August 2012, which caused water damage to the telemetry system on the north-facing slope.

\subsection{Calculation of descriptive statistics}

To provide an overview of the soil moisture content and groundwater level for different time/space locations, a selection of summary statistics was used. To summarise the distribution of data, we calculated the median and 5th, 25th, 75th and 95th percentiles for each data series. This allowed us to compare absolute soil water content and groundwater level between sites. However, we also wanted to compare the extent to which each location is likely to contribute to runoff, especially as runoff generation is typically conceptualised as a threshold process (Ali et al., 2013). We therefore additionally used statistics that described the wet extremes of the data. For soil moisture, we calculated the percentage of time that the soil was saturated, as this represents the condition where the location would generate subsurface flow and, if saturation reached the soil surface, overland flow. Soil saturation points were defined individually for each sensor, using the co-located groundwater well record to determine 
times when the water table intersected the sensor, and taking the average soil moisture reading at those times. These values were confirmed (and in two cases adjusted) based on visual inspection of the soil moisture time series. For groundwater level, we calculated the percentage of time that the water table level was above the 75th percentile. This quantifies locations where groundwater is closer to the surface and would therefore have faster lateral velocity according to typical findings that hydraulic conductivity decreases rapidly with depth (Beven and Kirkby, 1979).

To understand how total water storage in the catchment changes through the year, we estimated the water stored in the soil moisture and groundwater components. For soil moisture, we divided the catchment by soil type, according to the classification described in Sect. 2. For each type, we estimated total soil depth as the deepest functional soil horizon described in the S-Map database (Lilburne et al., 2004). The fraction soil moisture for soil from 0 to $45 \mathrm{~cm}$ depth was taken from the $30 \mathrm{~cm}$ sensor, and soil moisture for $45 \mathrm{~cm}$ depth to the base of the soil column was taken from the $60 \mathrm{~cm}$ sensor. For each time step, we derived the total soil moisture volume as

Total soil moisture $\left[\mathrm{m}^{3}\right]=\sum_{\text {SoilTypeAspect }} \sum_{\text {Area }}\left[\mathrm{m}^{2}\right]$

-Soil depth[m] f fraction soil moisture].

Dividing by total catchment area then gave average depth of soil water.

For groundwater, we do not know the total aquifer depth, and therefore use instead groundwater depth above minimum recorded. For each time step, we derived the variable groundwater storage above minimum as

Total groundwater $\left[\mathrm{m}^{3}\right]=\sum_{\text {Aspect }}\left[\right.$ Area $\left[\mathrm{m}^{2}\right] \cdot \sum_{\text {Wells }}$

(GW level [m] - Min. GW level [m]) /Number of wells].

Dividing by total catchment area then gave average depth of groundwater above minimum.

We recognise that this calculation involves a significant and uncertain extrapolation from the 32 soil moisture time series to the remainder of the $0.7 \mathrm{~km}^{2}$ catchment. However, given that the sensor locations were installed across aspect, distance from stream, and landscape position and depth, we anticipate that the estimated storage dynamics are a reasonable guide to true behaviour. We also note that, in the riparian zone, some water will be double counted where the groundwater rises into the soil column. However, given that this occurred only in near-stream locations, i.e. within $10 \mathrm{~m}$ of the stream centreline, this volume would be negligible compared to the total catchment storage.

\subsection{Event separation}

To compare rainfall and runoff depths for individual storm events, and to identify seasonal changes in the rainfall-runoff relationship, the data were pre-processed to define storm and inter-storm periods, based on the method of McMillan et al. (2014). The start of a storm was defined by a minimum rainfall intensity: either $2 \mathrm{~mm} \mathrm{~h}^{-1}$ or $10 \mathrm{~mm} \mathrm{day}^{-1}$ was required. The end of the storm was defined when $12 \mathrm{~h}$ without rainfall occurred. Runoff for a maximum of 5 days after rainfall ended, or until a new storm started, was deemed to be associated with the storm event. No baseflow separation was used.

\subsection{Wetting events}

To compare the frequency and strength of soil moisture responses to rainfall for different locations, we used the concept of a "wetting event". A wetting event was defined as a period of rainfall during which soil moisture rose by at least $3 \%$. We calculated events on a per-site basis, and then averaged across sites, either for northern/southern aspects or near-stream/far-stream sites. The average $\%$ soil moisture rise was used as an indication of the strength of response.

\section{Results}

\subsection{Temporal controls on soil moisture and groundwater}

Both soil moisture and groundwater level show strong variations over event and seasonal timescales. Figure 3 shows soil moisture, and depth to groundwater for the study period; for clarity we average the 32 soil moisture sensors and 14 water level sensors by location (aspect, depth and distance from stream).

In Fig. 4, we show the summary measures for each season. The summary statistics show that both the mean and extremes of catchment water storage vary seasonally. The yearly cycle of soil moisture (Fig. 3) shows an extended wet season from April/May to November, followed by a slow drying until February, when the catchment reaches its summer state. The return to wet conditions occurred over a very short time period during a May storm event. Water table dynamics also display a yearly cycle (Fig. 4), although the range during any season is large compared to seasonal changes. As shown in Fig. 4a, soil moisture quantiles are typically lowest in summer, and water tables are lowest in summer and autumn. The driest conditions in terms of extremes (Fig. 4b) occurred in late summer for both soil moisture and water table, and remain low into autumn, particularly for the water table, suggesting that the lowest potential for runoff generation occurs at that time. Note that the autumn season values represent an average between the wetter conditions of the 2012 autumn and the drier conditions of the 2013 autumn; 

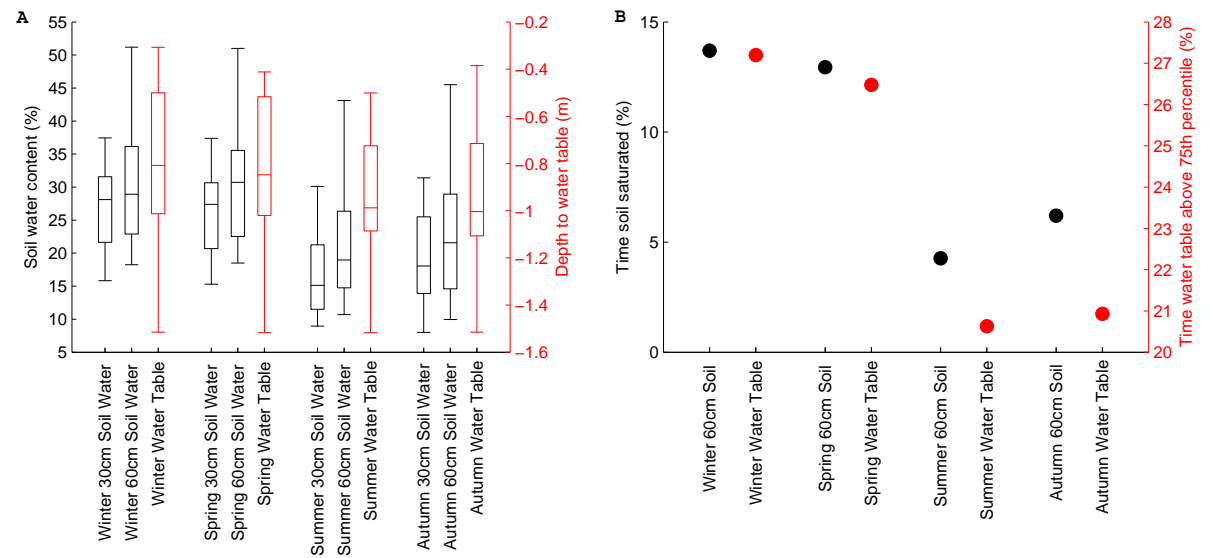

Figure 4. Summary statistics of soil moisture and depth to water table by season. (a) Distributions of measured values. (b) Summary of wet extremes.

for example, mean autumn (March-May) soil moisture at 0$30 \mathrm{~cm}$ for the upper rows of sensors was $17.9 \%$ for 2012 , $15.2 \%$ for 2013 .

Rainfall events are superimposed on the seasonal cycle. In winter, the large events cause saturation at many of the soil moisture sensors, and water tables rise in many of the wells, including some in the upper row where the water table was previously lower than the well. In early summer, rainfall can return soil moisture and water tables to winter levels, but only briefly. In summer, the catchment response to rainfall is highly subdued.

The strong seasonality of catchment conditions is due to seasonality in PET. Although rainfall depths are similar throughout the year, in summer the combination of higher temperatures, high solar radiation and frequent hot, strong winds from the northwest contributes to seasonal drying of the catchment. The effects are illustrated by storm runoff depths in winter vs. summer (Fig. 5a). In summer, even large rainfall events produced almost no streamflow response. To demonstrate the effect of antecedent wetness on storm runoff depths, we plotted runoff depth against the sum of antecedent soil moisture storage (ASM) and storm precipitation (Fig. 5b), following Detty and McGuire (2010b; their Fig. 4a). Antecedent soil moisture storage was taken as the total soil moisture value from Eq. (1). The results show a threshold relationship between ASM + precipitation and runoff depth, although it is not linear, as was found by Detty and McGuire (2010b).

\subsection{Spatial controls on soil moisture and groundwater}

Figure 3 shows distinct differences between the water storage dynamics on north-facing and south-facing slopes, and between the far-stream and near-stream rows of soil moisture sensors. The near-stream sensors on the south-facing slopes showed more frequent and pronounced wetting events, as defined in Sect. 3.7 (Table 4). South-facing slopes at $60 \mathrm{~cm}$
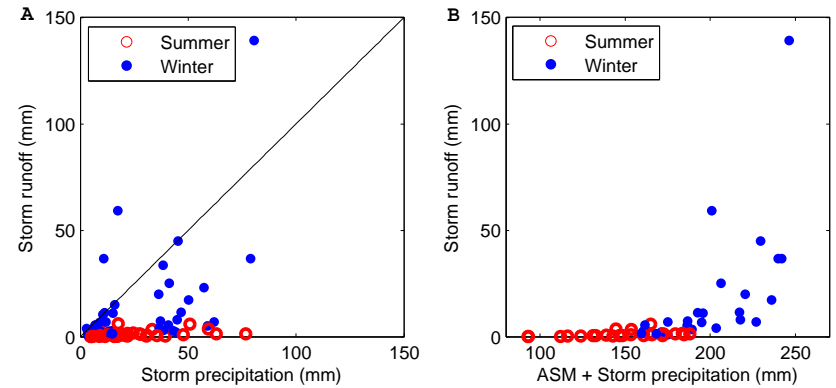

Figure 5. (a) Storm runoff against storm precipitation, split by season. The definition of a storm event is described in Sect. 3.6. No baseflow separation was used, leading to two events where storm runoff includes a component of pre-storm water and exceeds storm precipitation. (b) Storm runoff against the sum of storm precipitation and antecedent soil moisture storage (ASM), split by season. ASM was taken as the total soil moisture value from Eq. (1).

depth had $33 \%$ more wetting events that were on average $22 \%$ larger than north-facing slopes at $60 \mathrm{~cm}$ depth.

Spatial controls act differently on different water stores. These differences are illustrated in Fig. 6, using the same summary statistics as in the previous section, but grouping sites by aspect and distance from stream. We did not include water table statistics for the far-stream rows as water tables only rarely rose into the wells, and therefore distribution estimates would not be accurate. Figure 6a shows that when comparing north-facing vs. south-facing slopes, soil water content at $30 \mathrm{~cm}$ has similar distributions, but the underlying groundwater level is on average $20 \mathrm{~cm}$ closer to the ground surface for the south-facing slopes, and has a smaller range. Spatial controls also act differently on average vs. extreme conditions; e.g. average soil moisture on the south-facing slope is similar at 30 and $60 \mathrm{~cm}$ depths (Fig. 6a), but the fraction of time that the soil was saturated is $11 \%$ at $60 \mathrm{~cm}$ against $0.5 \%$ at $30 \mathrm{~cm}$ (Fig. 6b). Note that the statistics de- 

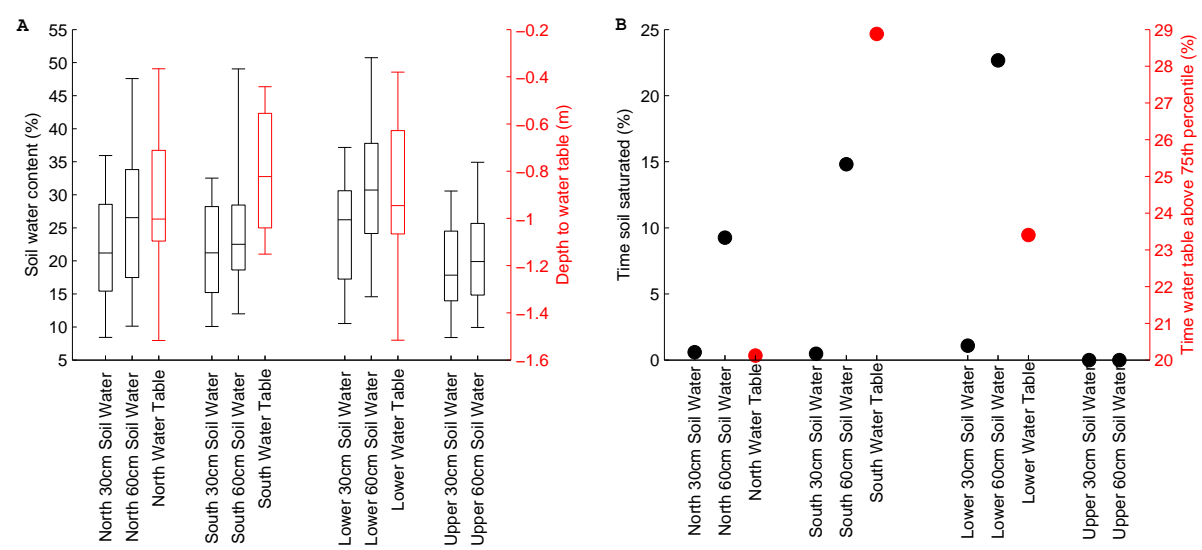

Figure 6. Summary statistics of soil moisture and depth to water table by location. (a) Distributions of measured values. (b) Summary of wet extremes.

Table 4. Number and size of soil moisture wetting events by aspect and distance from stream, where a wetting event is defined as a period of rainfall during which soil moisture at that location rose by at least $3 \%$.

\begin{tabular}{llrr}
\hline & $\begin{array}{l}\text { Number of } \\
\text { wetting } \\
\text { events }\end{array}$ & $\begin{array}{r}\text { Mean soil } \\
\text { moisture } \\
\text { increase } \\
\text { in the } 10 \\
\text { largest } \\
\text { events }\end{array}$ \\
& & 16 & $16 \%$ \\
& & 12 & $6 \%$ \\
\hline South-facing & Near-stream & 12 & $12 \%$ \\
& Far-stream & 9 & $6 \%$ \\
\hline North-facing & Near-stream & Far-stream &
\end{tabular}

scribing the extremes of the data are highly variable between locations (e.g. some locations are saturated much of the time; others, almost never); however, we show averages by location to assist interpretation of the spatial control.

\subsection{Temporal changes in total water storage and variability}

To quantify the relative importance of different water storage components of the catchment, we calculated the average depth of water stored as soil moisture and groundwater using the method described in Sect. 3.5 (Fig. 7a). The groundwater component dominates, with an average depth of $0.27 \mathrm{~m}$ against $0.15 \mathrm{~m}$ for soil moisture. The difference may be further enhanced given that the part of the soil moisture volume below wilting point is not likely to be mobilised. The difference is most pronounced in the wettest conditions, with groundwater storage peaking at approximately 4 times that of soil moisture. During the driest summer conditions, groundwater and soil moisture storage are similar.

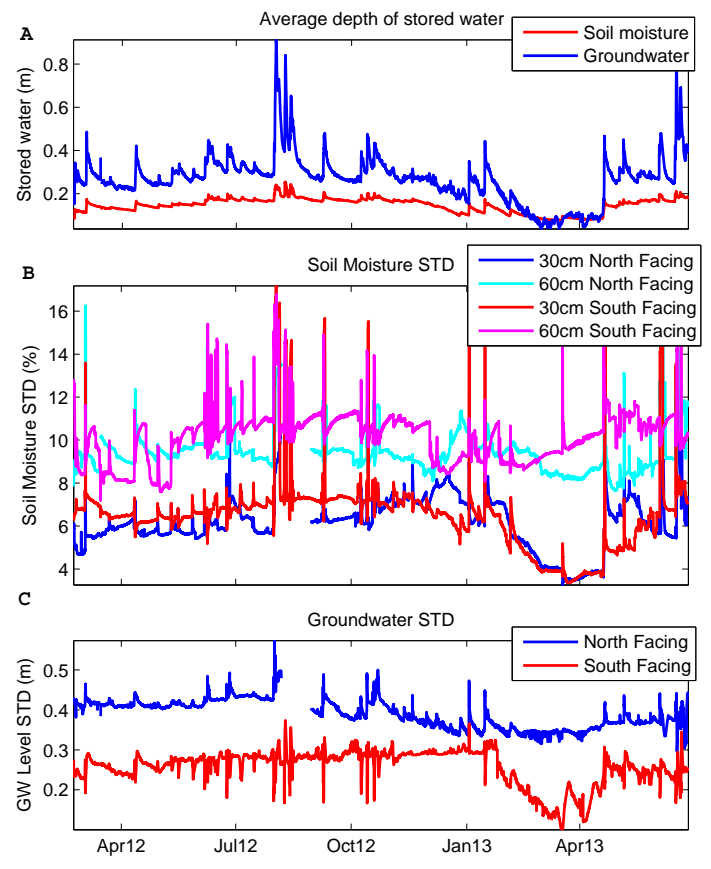

Figure 7. (a) Average depth of water stored in the catchment as soil moisture and groundwater. (b) Spatial standard deviation of soil moisture values, by aspect and depth. (c) Spatial standard deviation of groundwater levels, by aspect.

To visualise the changes in variability for each store over time, we plotted the time series of spatial standard deviation in soil moisture and groundwater, separated by aspect and sensor depth (Fig. 7b and c). All stores have the highest standard deviation in winter, and the lowest in summer, as the range in values tends to be compressed as the catchment dries out. Previous studies have shown that the relationship between soil moisture and soil moisture standard deviation varies by catchment (Sect. 1.1). Soil moisture at $60 \mathrm{~cm}$ maintains a high standard deviation even during summer, as both 

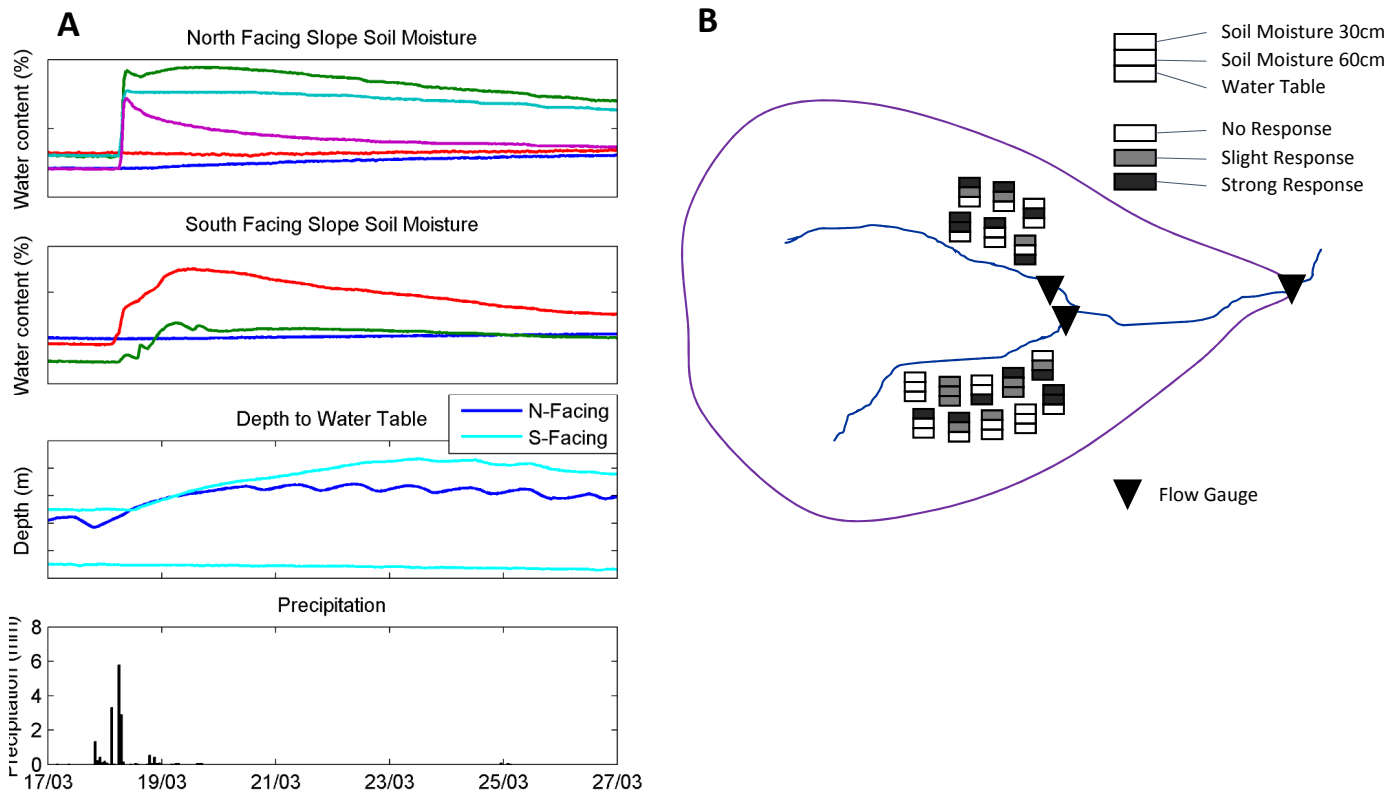

Figure 8. (a) Response of selected sensors to a March rainfall event. First and second panels: soil moisture responses in north-facing and south-facing slopes respectively. Colours are used only for visual clarity. Third panel: depth to water table. Fourth panel: storm precipitation. (b) Spatial overview of strength of soil moisture and water table sensor responses to the March rainfall event.

slopes have one sensor that retains high soil moisture and therefore has a strong influence on the standard deviation.

All of the soil moisture standard deviations rise sharply during rainfall events, especially in winter, which is due to saturation of some sensors, while others remained unsaturated. Accordingly, soil moisture at $30 \mathrm{~cm}$ on the north-facing slope has smaller rises in the spatial standard deviation, as none of those sensors showed saturation. Groundwater standard deviation has a different behaviour by aspect: on the north-facing slope, rainfall events cause the standard deviation to rise; on the south-facing slope, rainfall events cause the standard deviation to fall. This finding reflects that, on the south-facing slope, all wells react to rainfall events, albeit at different rates, but on the north-facing slope, behaviour is more variable, with one well often showing no response (i.e. water table lower than $1.5 \mathrm{~m}$ ), and other wells split between a weak or strong response.

\subsection{Controls on variability}

As was apparent from the time series of streamflow, soil moisture and water table depth presented in Sect. 3.1, there is significant spatial variability between different parts of the catchment as represented by the range of sensor locations, but this variability is not constant. In this section, we investigate the specific types of variability that occur, and seek to attribute them to different catchment conditions.

We found that an overarching driver of variability is the wetness condition of the catchment. As shown in Fig. 5, there is a strong seasonal differentiation in runoff coeffi- cients. This seasonal cycle determines which of the catchment water stores are active, and where the greatest scope for variability exists. To assist our description of the seasonal changes in variability, we selected one event that illustrates each variability type. We selected the following events: dry period: 17-27 March 2013, $15.9 \mathrm{~mm}$ rainfall; wet period: 5-25 October 2012, $164.9 \mathrm{~mm}$ rainfall; winter wetup: 15-30 April 2013, $80.0 \mathrm{~mm}$ rainfall; recession period: 7 September-5 October 2012.

\subsubsection{Dry-period variability caused by partial catchment response}

During the driest conditions, some locations show a hydrological response - an increase in soil moisture or water table rise - to a rainfall event, while the others show little or no reaction. The time of onset of this type of variability varies with depth for the soil moisture probes; i.e. $60 \mathrm{~cm}$ probes stop reacting earlier in the summer than $30 \mathrm{~cm}$ probes. The fact that shallow probes are more likely to react during dry conditions suggests that the variability is caused by infiltration of precipitation that only reaches a limited depth below the surface. An example is given in Fig. 8a, which shows the response of selected sensors to the March rainfall event. Figure $8 \mathrm{~b}$ shows a spatial overview of all sensor responses for the same event. For this event, eight of the $30 \mathrm{~cm}$ soil moisture probes showed a strong response, compared to three of the $60 \mathrm{~cm}$ soil moisture probes and three of the wells. There were two locations where the $60 \mathrm{~cm}$ probes responded but the $30 \mathrm{~cm}$ probes did not. As water tables were always below 

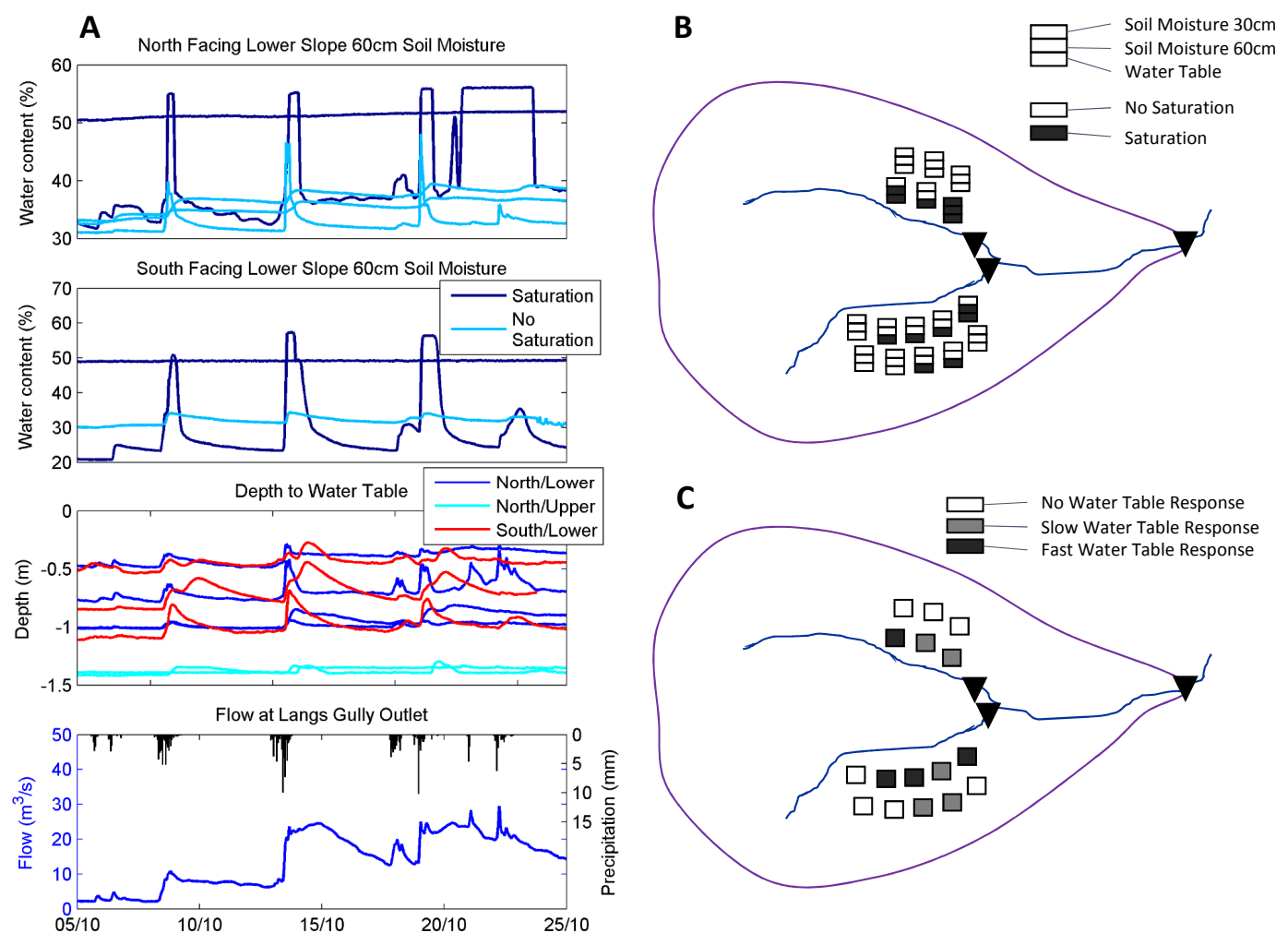

Figure 9. (a) Response of selected sensors to a winter rainfall event. First and second panels: soil moisture responses in north-facing and south-facing slopes respectively. Dark lines show sensors where saturation occurred. Third panel: depth to water table by well location. Fourth panel: storm precipitation and flow measured at the catchment outlet. (b) Overview of saturation response to the winter rainfall event. (c) Overview of rate of water table response to the winter rainfall event.

$60 \mathrm{~cm}$, these cases suggest macropore flow that bypassed the upper sensor. Four out of the 10 soil moisture probes at $30 \mathrm{~cm}$ on the north-facing slope showed no response, compared to 1 out of 6 on the south-facing slope. This difference may be due to drier antecedent conditions on the north-facing slope; north-facing sensors had a mean soil moisture of $9.6 \%$ prior to the rainfall event, compared to $11.4 \%$ for the south-facing sensors. Soil texture differences related to aspect may also play a role: south-facing sensor locations were found to have higher clay content and higher stone content than the northfacing locations.

\subsubsection{Wet-period variability caused by partial saturation and groundwater response timing}

In winter, the catchment is typically in a continuously wet state, and all sensors respond to rainfall events. Variability between sensors is introduced because some locations experience saturation (either transiently or for prolonged periods), while others do not. Saturation is characterised by high peaks or plateaux in the soil moisture signal. For both the northfacing and south-facing slopes, saturation occurs earlier and more extensively for probes at $60 \mathrm{~cm}$ than at $30 \mathrm{~cm}$, and is limited to the sites at $10 \mathrm{~m}$ from the stream, suggesting a rise in the catchment water table to these probes, rather than transient or perched saturated layers in the soil column. Crosschecking against measured groundwater levels also shows that the peaks in the water tables reach the soil moisture sensors showing saturation, although they do not typically reach the land surface. Wells in the upper locations may also react at this time. The rise in the near-stream water table into the soil is consistent with our knowledge of the soil and bedrock structures, as there are no evident confining layers, but rather an increase in cobbles and rock fragments with depth.

Figure 9 gives an example of the response of soil moisture and groundwater level to a series of storm events in October (three distinct peaks over 15 days) occurring on the alreadywet catchment. Saturation only occurs in 30 or $60 \mathrm{~cm}$ probes when the lower probes also show saturation. Three out of four locations where saturation at the $60 \mathrm{~cm}$ probes occurred in this event were locations that showed a water table response during the summer event previously described. All locations that had a water table response in the summer event also had a water table response during this event. The consistency of locations suggests that relative groundwater levels are maintained across seasons, with the same locations always the most likely to display a groundwater response. These locations were not related to the gully/ridge features 
in the catchment, in conflict with our prior hypothesis, but instead may indicate preferential groundwater flow paths which channel water from the upper slopes. Such preferential paths were previously reported at Maimai catchment where there is a clearly defined soil-bedrock interface (Graham et al., 2010; Woods and Rowe, 1996); our results suggest a similar outcome in the Langs Gully catchment despite the gradual transition from soil to broken bedrock. The cross-slope gradients needed to generate the preferential paths could be caused by deeper bedrock structures, or by local areas with high permeability such as the gravel-rich soil layers observed during installation of the soil moisture sensors. At Maimai, Woods and Rowe (1996) suggested that preferential flow paths were caused by temporary hydraulic gradients in the soil, and variations in vertical drainage due to patterns of soil moisture deficit.

Figure 9a (third panel) shows distinct differences in the timing of the groundwater response between locations. In some locations, there is a fast groundwater peak followed by a fast decline. In other locations, the groundwater rises more slowly, reaching a peak approximately $24 \mathrm{~h}$ later than the fast-response site, and is much slower to decline. The characterisation of each site as either a fast or slow responder is consistent through the three consecutive events. During some storm events, these two response types cause a double peak, or prolonged flat peak, in the storm hydrograph (lower panel). The differing responses are mapped in Fig. 9c. There is some spatial correlation with the saturation response shown in Fig. 9b, whereby locations with a flashy groundwater response correspond to locations where saturation occurred at the $60 \mathrm{~cm}$ soil moisture sensor. Locations where the water table was detected in the upper row of sensors were classified as slow groundwater responses (i.e. a later and prolonged peak), but they peak slightly before the downslope slow-response sites, which could indicate a delayed groundwater flow path from upslope.

Our results suggest that relative groundwater levels, and the classification of sites as fast or slow groundwater responses, are consistent between events. Previous work reviewed in the introduction (Sect. 1.3) showed that groundwater level can influence soil moisture distribution. We therefore hypothesise that groundwater behaviour might help to define distinct spatial zones of the catchment. To test this, we firstly classified sites by maximum groundwater level, separating sites where the water table rose as high as the $30 \mathrm{~cm}$ soil moisture probe at any point during the study period ("saturating sites"), against those where it did not ("nonsaturating sites"). We only used near-stream sites to remove the influence of distance to stream. Secondly, we classified sites by the rate of groundwater response, as described in the previous paragraph. Other sites where only the peaks of groundwater responses reached the shallow well were not included, as these sites could not be easily classified. We calculated the distributions of the soil moisture and water table level for each classification (Fig. 10). The results show that

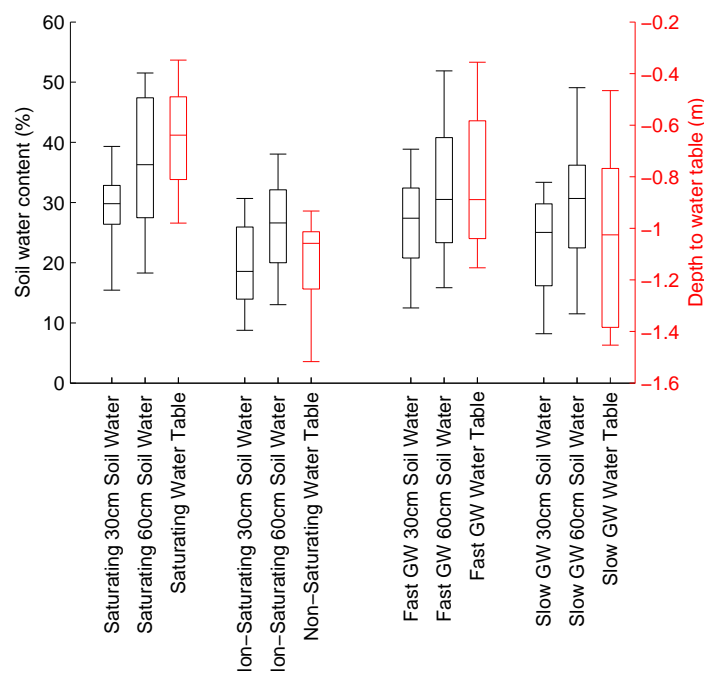

Figure 10. Distributions of soil moisture and depth to water table, classified as saturating/non-saturating sites, and fast/slow groundwater response sites. Saturating sites were defined as those where the water table rose as high as the $30 \mathrm{~cm}$ soil moisture probe at any point during the study period. Fast/slow sites were classified according to the rate of groundwater response as described in Sect. 4.4.2 and Fig. 9c.

the saturating vs. non-saturating classification clearly delineates two zones with consistent differences in soil moisture content at 30 and $60 \mathrm{~cm}$, and water table level. The fast vs. slow groundwater response classification is much less distinct, with the two zones having similar soil moisture distributions. The slow groundwater response zone has slightly deeper water tables, although this is partly because it includes two far-stream sites.

\subsubsection{Variability in seasonal dynamics: winter wet-up}

The wetting up of the catchment at the start of winter is a major event (Fig. 3). In 2013 this occurred in late April, quickly transitioning the catchment from its dry summer state to the wet state that it maintained throughout the winter. The typical pattern for soil moisture is a sharp rise over less than 24 h (e.g. Fig. 11a, red lines); however, some locations have a more gradual response (Fig. 11a, blue lines). On the southfacing slope, this sharp rise is reflected in a sharp water table rise in some locations, and a more gradual rise in others. On the north-facing slope, the water table rises only gradually in all locations (Fig. 11b and c). The two locations on the north-facing slope with gradual soil moisture response had a soil layer containing larger rocks $(5-10 \mathrm{~cm}$ diameter $)$ at $45-60 \mathrm{~cm}$ depth. This feature may promote fast drainage and therefore slow the soil wetting process.

The winter wet-up is a critical event in terms of flow prediction, as was previously shown in Fig. 5, which illustrates the stark differences in runoff coefficients in winter vs. summer. However, the spatial variation shown here in the rate 


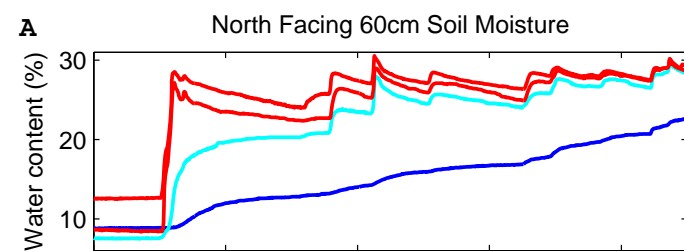

B

North Face Depth to Water Table
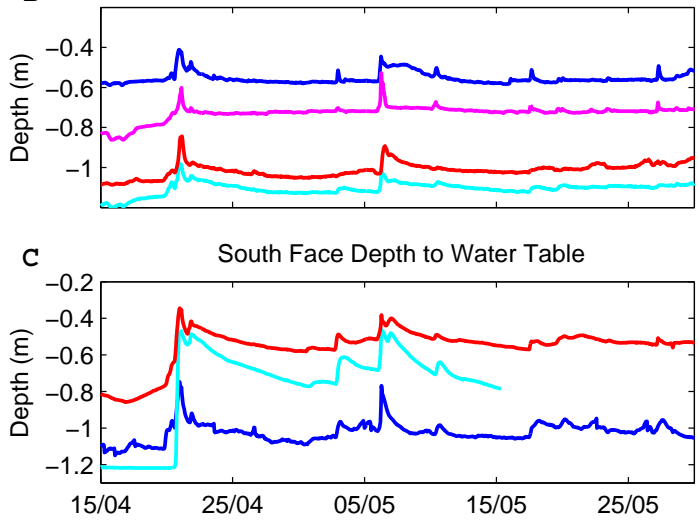

Figure 11. Winter wet-up response of selected soil moisture and water table sensors. (a) Soil moisture on the north-facing slope. Red lines show locations with a fast wet-up; blue lines show locations with a gradual wet-up. (b-C) Depth to water table at north-facing and south-facing slopes. Colours are used only for visual clarity.

and magnitude of the wet-up illustrates that it is a complex phenomenon which occurs differently for hillslopes with a different aspect.

\subsubsection{Variability in event dynamics: recession characteristics}

During a dry period, soil moisture, water table and flows undergo a recession. It is common to collate flow recessions to specify a master recession shape which can then be used directly to calculate model parameters related to baseflow generation. Recessions are typically expected to be a convex function of time; initial drying occurs quickly from loosely bound water, but drying slows as only more tightly bound water remains. In the Langs Gully catchment, we were surprised to find strong variations in recession shapes. This is illustrated in Fig. 12, which shows the recession shapes of soil moisture at $30 \mathrm{~cm}$ on the north-facing slope after a September rainfall event, including both convex and concave shapes. We found that, at different times of the year, the same soil moisture sensor at the same soil moisture content could display either convex or concave behaviour, suggesting that this finding is not an artefact of the soil moisture sensor calibration or the particular soil tension characteristics. We also found that the shape (i.e. convex or concave) of the corresponding $60 \mathrm{~cm}$ soil moisture response was typically the same as the $30 \mathrm{~cm}$ sensor (not shown). It can also occur across the range of soil moisture contents. Instead, the difference in recession

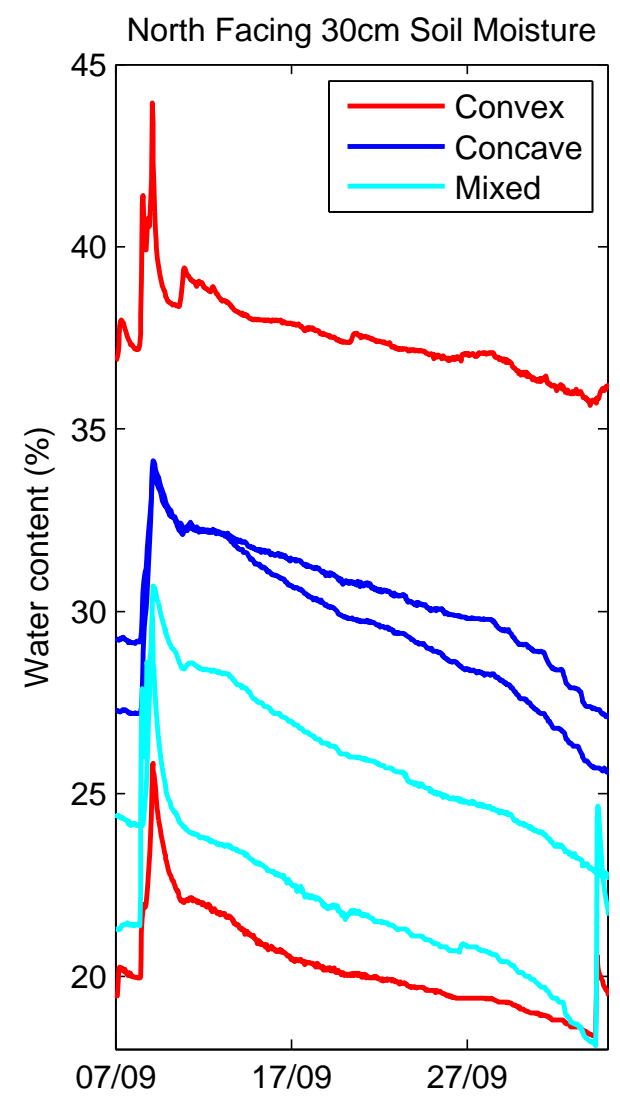

Figure 12. Selected north-facing $30 \mathrm{~cm}$ soil moisture sensor responses during a recession, having convex, concave or mixed response function shapes.

shapes could be due to either transient downslope flow towards the sensor, similar to the theoretical case described by Henderson and Wooding (1964), or seasonally varying vegetation characteristics. For example, the unusual concave responses could be due to plants exhausting near-surface soil water stores and therefore starting to extract water from the slightly deeper location of the soil moisture sensor.

\section{Summary and implications of variability}

Our results have shown multiple modes of spatial and temporal variability in storage in the Langs Gully catchment. Here we summarise the temporal variability in soil moisture and groundwater, followed by spatial variability in soil moisture and groundwater. We then consider connections between them, i.e. temporal changes in spatial variability. Lastly we consider implications of variability for catchment runoff response and prediction.

\subsection{Temporal variability}

Temporal variability is characterised by a strong seasonal cycle in catchment wetness; the mean and extremes of the soil 
moisture and water table distributions are higher in winter than summer. The cycle is driven by PET rather than rainfall depth, and causes significantly higher runoff coefficients in winter. The seasonal cycle in soil moisture shows a long, high winter plateau compared to water table levels that respond mainly to individual events. The catchment wets up quickly in autumn, but takes longer to dry out in spring, and spring rainfall can briefly return soil moisture and water table levels to their winter state. The volume of stored water in the catchment also has a seasonal cycle, mostly due to increased groundwater in winter, especially during the largest storms.

\subsection{Spatial variability}

Spatial variability is controlled most strongly by aspect and distance from stream. South-facing slopes have similar mean soil moisture to north-facing slopes, but more events lead to a soil moisture response, and experience soil saturation more often. Water table levels are higher in south-facing slopes and more consistent between locations within the southfacing slope. Near-stream locations have higher soil moisture for both mean and extremes, and experience more wetting events. Near-stream locations frequently record saturation in winter, whereas far-stream locations have water tables below the soil moisture sensors and the $1.5 \mathrm{~m}$ wells for almost the whole study period. We found a strong interaction between groundwater level and soil moisture distribution. Sites where water tables peaked above the $30 \mathrm{~cm}$ sensor had a significantly higher soil moisture distribution compared to sites where water table remained below $30 \mathrm{~cm}$ for the whole study period. The finding that soil moisture distribution is dependent on water table depth agrees with measurements in Nordic catchments by Beldring et al. (1999).

Our conclusion that aspect is an important control on soil moisture echoes the results of previous studies in NZ hill country (e.g. Bretherton et al., 2010; Lambert and Roberts, 1976). The mechanisms linking aspect with soil moisture are varied. For example, Lambert and Roberts (1976) found complex interactions between air temperature, soil temperature and ET, driven by wind direction and aspect-induced radiation differences. They note that the specific heat capacity of soil drops as it dries, leading to a positive feedback cycle. In the Langs Gully catchment, the south-facing slopes are also steeper than the north-facing slopes. This is not obviously due to geological bedding - the main trend of syncline-anticline pairs in the wider Waipara catchment is northwest-southeast (transverse to catchment slopes), and in the immediate area of Langs Gully, known dip directions are highly variable. However, feedbacks are likely to exist between slope angle, vegetation (denser shrub cover on southfacing slopes), soil depth (thinner on south-facing slopes) and downslope sediment transport. Shading by denser vegetation and increased lateral flow are possible causes of the increased number of wetting events on the south-facing slope. Typical hydrological models do not account for aspect, but

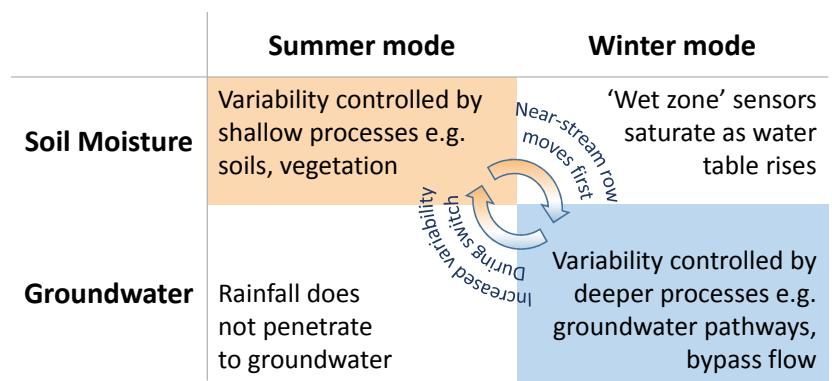

Figure 13. Schematic diagram of the seasonal cycle of catchment variability between "Summer mode" and "Winter mode".

our results suggest that this is an important factor to consider in hillslope runoff generation.

\subsection{Temporal changes in spatial variability}

We suggest that spatial variability can be classified as being in "summer mode" or "winter mode". These modes are illustrated as a schematic diagram in Fig. 13. In "summer mode", variability is controlled by shallow processes, e.g. interaction of water with soils and vegetation. Water does not typically penetrate to deeper soil moisture or groundwater. Summer variability is therefore disconnected from the channel, and will not directly affect the flow response. However, summer variability affects land surface processes such as evapotranspiration, and may have a lagged effect on the autumn/winter wetting-up process. An example of the disconnect is that the $30 \mathrm{~cm}$ soil moisture sites that reacted most strongly to the selected summer rainfall event did not correspond to the "saturating" sites identified in Sect. 4.4.2 as having consistently wetter soil moisture and shallow water tables.

In "winter mode", variability is controlled by deeper processes, e.g. groundwater movement and bypass flow. The change from shallow vertical flow in dry conditions to vertical bypass flow and lateral flows from upslope in wet conditions is very similar to that found by Detty and McGuire (2010a). However, the summer and winter modes in Langs Gully differ from those found by Bachmair et al. (2012). In their catchment, intense summer storms onto dry soil caused preferential flow and fast, strong, spatially variable water table responses throughout the hillslope. In contrast, their winter storms led to slower water table responses that were strongest at near-stream locations.

In the shoulder seasons, there is a spatially variable shift between the summer and winter modes. Sensors in nearstream locations, particularly those with responsive water tables, stay longer in winter mode. As locations switch between summer and winter modes at varying rates, spatial variability is increased. This effect is particularly evident on the north-facing slope, where soil moisture standard deviation at 30 and $60 \mathrm{~cm}$ has a sustained rise during the spring drying period. Rosenbaum et al. (2012) similarly found that 
seasonal differences between groundwater-influenced and groundwater-distant locations had a strong effect on soil moisture standard deviation. This effect provides one explanation for why high spatial and temporal variabilities tend to co-occur, as has been found in previous work in New Zealand (McMillan et al., 2014).

\subsection{Implications for prediction of runoff generation}

It is common for some parts of the Langs Gully catchment to wet up or become saturated, and hence potentially contribute to a runoff response, while other parts of the catchment remain dry. Near-stream and south-facing locations have higher water tables and experience more wetting events. We were able to classify the near-stream sensors into "saturating zones" and "non-saturating zones". The saturating zones had higher water table and wetter soil moisture distributions. These zones remained distinct throughout the year.

The saturating zones are likely to be dominant areas for runoff generation, as wetter soils facilitate vertical drainage and high water tables increase lateral transmissivity. For example, Jencso et al. (2010) found that connectivity between hillslopes and riparian zones led to fast turnover times of riparian groundwater. However, the saturating/non-saturating zones did not correspond to the pattern of sensors wetted by infiltration during a summer storm event. The different patterns imply that shallow soil moisture storm responses may not provide a good guide to winter runoff generation pathways, as also found by Tromp-van Meerveld and McDonnell (2005). Rainfall-runoff model structures that delineate catchment landscape components according to dominant processes (e.g. Gharari et al., 2011) may need to use different spatial disaggregations for shallow soil water and groundwater.

Understanding catchment variability has further implications for predictions of catchment behaviour. Variability controls which parts of the catchment are generating runoff and controlling water partitioning: it therefore controls uncertainty in flow predictions, depending on our knowledge or lack of knowledge about those water stores or fluxes. Similarly, variability controls how quickly water flows through a catchment, as the different response modes direct water into flow paths with different transit times (Heidbuechel et al., 2013). Variability also provides clues into unmeasured fluxes which are important for catchment response; for example, areas with more rapid water table movement suggest locations of preferential flow paths, either vertical or horizontal. Signatures of the catchment variability are seen in the flow response, such as a double or prolonged peak caused by slower groundwater pathways (also found by Bachmair et al., 2012), and seasonally variable changes in contributions between different hillslopes. These features suggest that understanding catchment-scale variability in hydrological processes is essential for predicting the hydrograph.

\section{Conclusions}

We made distributed measurements of flow, soil moisture and depth to groundwater in a New Zealand headwater catchment, to characterise controls on variability in hydrological responses to rainfall events. The data showed that temporal variability in soil moisture was dominated by a strong seasonal cycle in PET and resulting moisture content, with event dynamics superimposed. The volume of stored water in the catchment had a corresponding seasonal cycle, mostly due to increased groundwater in winter. Spatial variability is controlled most strongly by aspect and distance from stream: south-facing and near-stream sites are typically wetter, and in particular have more and larger wetting events. The relative wetness of different locations was stable: high water table locations were consistent across seasons, and sites where water tables peaked above $30 \mathrm{~cm}$ depth had consistently wetter soils. Temporal dynamics vary spatially, including timing of winter wet-up (faster on south-facing slopes), different rates of groundwater response (slow at far-stream sites) and different recession shapes (no clear spatial pattern).

We examined soil moisture and groundwater responses to rainfall, for dry vs. wet antecedent conditions, and found significant differences in the patterns of response. This led us to classify catchment variability as being in "summer mode" or "winter mode". In "summer mode", variability is controlled by shallow processes, e.g. interaction between water and soils and vegetation, and sites where soil moisture reacts strongly to a rainfall event may not correspond to the usual wetter locations. In "winter mode", variability is controlled by deeper processes, e.g. groundwater movement and bypass flow. In both cases, variability is strongest for stores where water content is typically close to a threshold such as saturation. Because spatial variability changes with season, we suggest that methods to predict emergent catchment behaviour arising from small-scale variability in storage may also need to change with season.

Acknowledgements. The authors would like to thank the Editor Ilja van Meerveld and two anonymous referees for their thorough and helpful reviews. We thank the NIWA Christchurch field and instrument system teams, and land owners Dugald and Mandy Rutherford. This research was funded by the NZ Ministry of Business, Innovation and Employment, contract C01X1006: "Waterscape".

Edited by: I. van Meerveld 


\section{References}

Acclima: SDI-12 Sensor Data Sheet: http://acclima.com/wd/ acclimadocs/agriculture/SDI-12_TDT_Sensor_Data_Sheet.pdf, last access: 1 November 2014.

Ali, G., Oswald, C. J., Spence, C., Cammeraat, E. L. H., McGuire, K. J., Meixner, T., and Reaney, S. M.: Towards a unified threshold-based hydrological theory: necessary components and recurring challenges, Hydrol. Process., 27, 313-318, doi:10.1002/hyp.9560, 2013.

Anderson, M. G. and Burt, T. P.: The role of topography in controlling throughflow generation, Earth Surf. Proc. Land., 3, 331-344, 1978.

Beldring, S., Gottschalk, L., Seibert, J., and Tallaksen, L. M.: Distribution of soil moisture and groundwater levels at patch and catchment scales, Agricultural and Forest Meteorology, 98-9, 305-324, 10.1016/s0168-1923(99)00103-3, 1999.

Bachmair, S., Weiler, M., and Troch, P. A.: Intercomparing hillslope hydrological dynamics: Spatio-temporal variability and vegetation cover effects, Water Resour. Res., 48, W05537, doi:10.1029/2011wr011196, 2012.

Beven, K. and Germann, P.: Macropores and water flow in soils revisited, Water Resour. Res., 49, 3071-3092, doi:10.1002/wrcr.20156, 2013.

Beven, K. and Kirkby, M. J.: A physically based variable contributing area model of basin hydrology, Hydrol. Sci. Bull., 24, 43-69, 1979.

Bidwell, V. J., Stenger, R., and Barkle, G. F.: Dynamic analysis of groundwater discharge and partial-area contribution to Pukemanga Stream, New Zealand, Hydrol. Earth Syst. Sci., 12, 975987, doi:10.5194/hess-12-975-2008, 2008.

Binley, A., Ullah, S., Heathwaite, A. L., Heppell, C., Byrne, P., Lansdown, K., Trimmer, M., and Zhang, H.: Revealing the spatial variability of water fluxes at the groundwatersurface water interface, Water Resour. Res., 49, 3978-3992, doi:10.1002/wrcr.20214, 2013.

Blöschl, G. and Sivapalan, M.: Scale Issues in Hydrological Modeling - A Review, Hydrol. Process., 9, 251-290, 1995.

Bretherton, M. R., Scotter, D. R., Horne, D. J., and Hedley, M. J.: Towards an improved understanding of the soil water balance of sloping land under pasture, New Zeal. J. Agr. Res., 53, 175-185, 2010.

Brocca, L., Morbidelli, R., Melone, F., and Moramarco, T.: Soil moisture spatial variability in experimental areas of central Italy, J. Hydrol., 333, 356-373, doi:10.1016/j.jhydrol.2006.09.004, 2007.

Bronstert, A. and Bárdossy, A.: The role of spatial variability of soil moisture for modelling surface runoff generation at the small catchment scale, Hydrol. Earth Syst. Sci., 3, 505-516, doi:10.5194/hess-3-505-1999, 1999.

Chen, X. and $\mathrm{Hu}, \mathrm{Q}$.: Groundwater influences on soil moisture and surface evaporation, J. Hydrol., 297, 285-300, doi:10.1016/j.jhydrol.2004.04.019, 2004.

Crave, A. and Gascuel-Odoux, C.: The influence of topography on time and space distribution of soil surface water content, Hydrol. Process., 11, 203-210, 1997.

Detty, J. M. and McGuire, K. J.: Topographic controls on shallow groundwater dynamics: implications of hydrologic connectivity between hillslopes and riparian zones in a till mantled catchment, Hydrol. Process., 24, 2222-2236, doi:10.1002/hyp.7656, 2010a.
Detty, J. M. and McGuire, K. J.: Threshold changes in storm runoff generation at a till-mantled headwater catchment, Water Resour. Res., 46, W07525, doi:10.1029/2009wr008102, 2010 b.

Eger, A. and Hewitt, A.: Soils and their relationship to aspect and vegetation history in the eastern Southern Alps, Canterbury High Country, South Island, New Zealand, Catena, 75, 297-307, doi:10.1016/j.catena.2008.07.008, 2008.

Entin, J. K., Robock, A., Vinnikov, K. Y., Hollinger, S. E., Liu, S. X., and Namkhai, A.: Temporal and spatial scales of observed soil moisture variations in the extratropics, J. Geophys. Res.Atmos., 105, 11865-11877, doi:10.1029/2000jd900051, 2000.

Famiglietti, J. S., Ryu, D., Berg, A. A., Rodell, M., and Jackson, T. J.: Field observations of soil moisture variability across scales, Water Resour. Res., 44, W01423, doi:10.1029/2006wr005804, 2008.

Fenicia, F., Wrede, S., Kavetski, D., Pfister, L., Hoffmann, L., Savenije, H. H. G., and McDonnell, J. J.: Assessing the impact of mixing assumptions on the estimation of streamwater mean residence time, Hydrol. Process., 24, 1730-1741, 2010.

Freer, J., McDonnell, J. J., Beven, K. J., Peters, N. E., Burns, D. A., Hooper, R. P., Aulenbach, B., and Kendall, C.: The role of bedrock topography on subsurface storm flow, Water Resour. Res., 38, 1269, doi:10.1029/2001wr000872, 2002.

Freer, J., McMillan, H., McDonnell, J. J., and Beven, K. J.: Constraining dynamic TOPMODEL responses for imprecise water table information using fuzzy rule based performance measures, J. Hydrol., 291, 254-277, 2004.

Fujimoto, M., Ohte, N., and Tani, M.: Effects of hillslope topography on hydrological responses in a weathered granite mountain, Japan: comparison of the runoff response between the valley-head and the side slope, Hydrol. Process., 22, 2581-2594, doi:10.1002/hyp.6857, 2008.

Gabrielli, C. P., McDonnell, J. J., and Jarvis, W. T.: The role of bedrock groundwater in rainfall-runoff response at hillslope and catchment scales, J. Hydrol., 450, 117-133, doi:10.1016/j.jhydrol.2012.05.023, 2012.

Gharari, S., Hrachowitz, M., Fenicia, F., and Savenije, H. H. G.: Hydrological landscape classification: investigating the performance of HAND based landscape classifications in a central European meso-scale catchment, Hydrol. Earth Syst. Sci., 15, 3275-3291, doi:10.5194/hess-15-3275-2011, 2011.

Gleeson, T., Novakowski, K., and Kyser, T. K.: Extremely rapid and localized recharge to a fractured rock aquifer, J. Hydrol., 376, 496-509, doi:10.1016/j.jhydrol.2009.07.056, 2009.

Graham, C. B. and McDonnell, J. J.: Hillslope threshold response to rainfall: (2) Development and use of a macroscale model, J Hydrol., 393, 77-93, doi:10.1016/j.jhydrol.2010.03.008, 2010.

Graham, C. B., Woods, R. A., and McDonnell, J. J.: Hillslope threshold response to rainfall: (1) A field based forensic approach, J. Hydrol., 393, 65-76, doi:10.1016/j.jhydrol.2009.12.015, 2010.

Grayson, R. B. and Western, A. W.: Towards areal estimation of soil water content from point measurements: time and space stability of mean response, J. Hydrol., 207, 68-82, doi:10.1016/s00221694(98)00096-1, 1998.

Grayson, R. B. and Bloschl, G.: Spatial Processes, Organisation and Patterns, in: Spatial Patterns in Catchment Hydrology: Observations and Modelling, edited by: Grayson, R. B. and Bloschl, G., Cambridge University Press, Cambridge, 1-16, 2000. 
Grayson, R. B., Bloschl, G., Western, A. W., and McMahon, T. A.: Advances in the use of observed spatial patterns of catchment hydrological response, Adv. Water Resour., 25, 1313-1334, doi:10.1016/s0309-1708(02)00060-x, 2002.

Gupta, H. V., Perrin, C., Blöschl, G., Montanari, A., Kumar, R., Clark, M., and Andréassian, V.: Large-sample hydrology: a need to balance depth with breadth, Hydrol. Earth Syst. Sci., 18, 463477, doi:10.5194/hess-18-463-2014, 2014.

Haria, A. H. and Shand, P.: Evidence for deep sub-surface flow routing in forested upland Wales: implications for contaminant transport and stream flow generation, Hydrol. Earth Syst. Sci., 8, 334-344, doi:10.5194/hess-8-334-2004, 2004.

Harman, C. and Sivapalan, M.: A similarity framework to assess controls on shallow subsurface flow dynamics in hillslopes, Water Resour. Res., 45, W01417, doi:10.1029/2008wr007067, 2009.

Haught, D. R. W. and Meerveld, H. J.: Spatial variation in transient water table responses: differences between an upper and lower hillslope zone, Hydrol. Process., 25, 3866-3877, doi:10.1002/hyp.8354, 2011.

Heidbuechel, I., Troch, P. A., and Lyon, S. W.: Separating physical and meteorological controls of variable transit times in zero-order catchments, Water Resour. Res., 49, 7644-7657, doi:10.1002/2012wr013149, 2013.

Henderson, F. M. and Wooding, R. A.: Overland flow and groundwater flow from a steady rainfall of finite duration, J. Geophys. Res., 69, 1531-1540, 1964.

Jackson, R. J.: The effect of slope, aspect and albedo on potential evapotranspiration from hillslopes and catchments, J. Hydrol., 6, 60-69, 1967.

Jencso, K. G., McGlynn, B. L., Gooseff, M. N., Bencala, K. E., and Wondzell, S. M.: Hillslope hydrologic connectivity controls riparian groundwater turnover: Implications of catchment structure for riparian buffering and stream water sources, Water Resour. Res., 46, W10524, doi:10.1029/2009wr008818, 2010.

Kaplan, D. and Munoz-Carpena, R.: Complementary effects of surface water and groundwater on soil moisture dynamics in a degraded coastal floodplain forest, J. Hydrol., 398, 221-234, doi:10.1016/j.jhydrol.2010.12.019, 2011.

Kavetski, D., Kuczera, G., and Franks, S. W.: Calibration of conceptual hydrological models revisited: 1. Overcoming numerical artefacts, J. Hydrol., 320, 173-186, doi:10.1016/j.jhydrol.2005.07.012, 2006.

Kim, C. P., Salvucci, G. D., and Entekhabi, D.: Groundwatersurface water interaction and the climatic spatial patterns of hillslope hydrological response, Hydrol. Earth Syst. Sci., 3, 375-384, doi:10.5194/hess-3-375-1999, 1999.

Kim, S., Lee, H., Woo, N. C., and Kim, J.: Soil moisture monitoring on a steep hillside, Hydrol. Process., 21, 2910-2922, doi:10.1002/hyp.6508, 2007.

Kirchner, J. W.: Getting the right answers for the right reasons: Linking measurements, analyses, and models to advance the science of hydrology, Water Resour. Res., 42, W03s04, doi:10.1029/2005wr004362, 2006.

Kosugi, K. I., Katsura, S. Y., Mizuyama, T., Okunaka, S., and Mizutani, T.: Anomalous behavior of soil mantle groundwater demonstrates the major effects of bedrock groundwater on surface hydrological processes, Water Resour. Res., 44, W01407, doi:10.1029/2006wr005859, 2008.
Kosugi, K. I., Fujimoto, M., Katsura, S. Y., Kato, H., Sando, Y., and Mizuyama, T.: Localized bedrock aquifer distribution explains discharge from a headwater catchment, Water Resour. Res., 47, W07530, doi:10.1029/2010wr009884, 2011.

Lambert, M. G. and Roberts, E.: Aspect differences in an unimproved hill country pasture, I. Climatic differences, New Zeal. J. Agr. Res., 19, 459-467, 1976.

Lana-Renault, N., Regues, D., Serrano, P., and Latron, J.: Spatial and temporal variability of groundwater dynamics in a subMediterranean mountain catchment, Hydrol. Process., 28, 32883299, doi:10.1002/hyp.9892, 2014.

Lehmann, P., Hinz, C., McGrath, G., Tromp-van Meerveld, H. J., and McDonnell, J. J.: Rainfall threshold for hillslope outflow: an emergent property of flow pathway connectivity, Hydrol. Earth Syst. Sci., 11, 1047-1063, doi:10.5194/hess-11-10472007, 2007.

Lilburne, L., Hewitt, A., Webb, T. H., and Carrick, S.: S-map: a new soil database for New Zealand, Proceedings of SuperSoil 2004: 3rd Australian New Zealand Soils Conference, Sydney, Australia, 1-8, 2004.

Lowry, T. S., Bright, J. C., Close, M. E., Robb, C. A., White, P. A., and Cameron, S. G.: Management gaps analysis: A case study of groundwater resource management in New Zealand, Int. J. Water Resour. Develop., 19, 579-592, doi:10.1080/0790062032000161382, 2003.

McDonnell, J. J.: A rationale for old water discharge through macropores in a steep, humid catchment, Water Resour. Res., 26, 2821-2832, 1990.

McGlynn, B. L., McDonnel, J. J., and Brammer, D. D.: A review of the evolving perceptual model of hillslope flowpaths at the Maimai catchments, New Zealand, J. Hydrol., 257, 1-26, 2002.

McMillan, H.: Effect of spatial variability and seasonality in soil moisture on drainage thresholds and fluxes in a conceptual hydrological model, Hydrol. Process., 26, 2838-2844, 2012.

McMillan, H., Gueguen, M., Grimon, E., Woods, R., Clark, M., and Rupp, D. E.: Spatial variability of hydrological processes and model structure diagnostics in a $50 \mathrm{~km}^{2}$ catchment, Hydrol. Process., 28, 4896-4913, doi:10.1002/hyp.9988, 2014.

Michot, D., Benderitter, Y., Dorigny, A., Nicoullaud, B., King, D., and Tabbagh, A.: Spatial and temporal monitoring of soil water content with an irrigated corn crop cover using surface electrical resistivity tomography, Water Resour. Res., 39, W01138, doi:10.1029/2002wr001581, 2003.

Moore, R. J.: The PDM rainfall-runoff model, Hydrol. Earth Syst. Sci., 11, 483-499, doi:10.5194/hess-11-483-2007, 2007.

Njoku, E. G., Wilson, W. J., Yueh, S. H., Dinardo, S. J., Li, F. K., Jackson, T. J., Lakshmi, V., and Bolten, J.: Observations of soil moisture using a passive and active low-frequency microwave airborne sensor during SGP99, IEEE T. Geosci. Remote, 40, 2659-2673, doi:10.1109/tgrs.2002.807008, 2002.

Nyberg, L.: Spatial variability of soil water content in the covered catchment at Gardsjon, Sweden, Hydrol. Process., 10, 89-103, 1996.

Onda, Y., Komatsu, Y., Tsujimura, M., and Fujihara, J.: The role of subsurface runoff through bedrock on storm flow generation, Hydrol. Process., 15, 1693-1706, doi:10.1002/hyp.234, 2001.

Parlange, M. B., Steenhuis, T. S., Timlin, D. J., Stagnitti, F., and Bryant, R. B.: Subsurface flow above a fragipan horizon, Soil Sci., 148, 77-86, 1989. 
Penna, D., Borga, M., Norbiato, D., and Fontana, G. D.: Hillslope scale soil moisture variability in a steep alpine terrain, J. Hydrol., 364, 311-327, doi:10.1016/j.jhydrol.2008.11.009, 2009.

Qiu, Y., Fu, B. J., Wang, J., and Chen, L. D.: Soil moisture variation in relation to topography and land use in a hillslope catchment of the Loess Plateau, China, J. Hydrol., 240, 243-263, doi:10.1016/s0022-1694(00)00362-0, 2001.

Rosenbaum, U., Bogena, H. R., Herbst, M., Huisman, J. A., Peterson, T. J., Weuthen, A., Western, A. W., and Vereecken, H.: Seasonal and event dynamics of spatial soil moisture patterns at the small catchment scale, Water Resour. Res., 48, W10544, doi:10.1029/2011wr011518, 2012.

Ryu, D. and Famiglietti, J. S.: Characterization of footprint-scale surface soil moisture variability using Gaussian and beta distribution functions during the Southern Great Plains 1997 (SGP97) hydrology experiment, Water Resour. Res., 41, W12433, doi:10.1029/2004wr003835, 2005.

Schmidt, J. and Hewitt, A.: Fuzzy land element classification from DTMs based on geometry and terrain position, Geoderma, 121, 243-256, doi:10.1016/j.geoderma.2003.10.008, 2004.

Seneviratne, S. I., Corti, T., Davin, E. L., Hirschi, M., Jaeger, E. B., Lehner, I., Orlowsky, B., and Teuling, A. J.: Investigating soil moisture-climate interactions in a changing climate: A review, Earth-Sci. Rev., 99, 125-161, doi:10.1016/j.earscirev.2010.02.004, 2010.

Sidle, R. C.: Field observations and process understanding in hydrology: essential components in scaling, Hydrol. Process., 20, 1439-1445, doi:10.1002/hyp.6191, 2006.

Soulsby, C., Tetzlaff, D., van den Bedem, N., Malcolm, I. A., Bacon, P. J., and Youngson, A. F.: Inferring groundwater influences on surface water in montane catchments from hydrochemical surveys of springs and streamwaters, J. Hydrol., 333, 199-213, doi:10.1016/j.jhydrol.2006.08.016, 2007.

Soulsby, C., Neal, C., Laudon, H., Burns, D. A., Merot, P., Bonell, M., Dunn, S. M., and Tetzlaff, D.: Catchment data for process conceptualization: simply not enough?, Hydrol. Process., 22, 2057-2061, doi:10.1002/hyp.7068, 2008.

Tetzlaff, D., McDonnell, J. J., Uhlenbrook, S., McGuire, K. J., Bogaart, P. W., Naef, F., Baird, A. J., Dunn, S. M., and Soulsby, C.: Conceptualizing catchment processes: simply too complex?, Hydrol. Process., 22, 1727-1730, doi:10.1002/hyp.7069, 2008.

Teuling, A. J. and Troch, P. A.: Improved understanding of soil moisture variability dynamics, Geophys. Res. Lett., 32, L05404, doi:10.1029/2004g1021935, 2005.

Teuling, A. J., Uijlenhoet, R., and Troch, P. A.: On bimodality in warm season soil moisture observations, Geophys. Res. Lett., 32, L13402, doi:10.1029/2005g1023223, 2005.

Teuling, A. J., Uijlenhoet, R., Hupet, F., van Loon, E. E., and Troch, P. A.: Estimating spatial mean root-zone soil moisture from point-scale observations, Hydrol. Earth Syst. Sci., 10, 755767, doi:10.5194/hess-10-755-2006, 2006.

Teuling, A. J., Hupet, F., Uijlenhoet, R., and Troch, P. A.: Climate variability effects on spatial soil moisture dynamics, Geophys. Res. Lett., 34, L06406, doi:10.1029/2006g1029080, 2007.

Tiedeman, C. R., Goode, D. J., and Hsieh, P. A.: Characterizing a ground water basin in a new England mountain and valley terrain, Ground Water, 36, 611-620, doi:10.1111/j.17456584.1998.tb02835.x, 1998.
Troch, P. A., Carrillo, G. A., Heidbuchel, I., Rajagopal, S., Switanek, M., Volkmann, T. H. M., and Yaeger, M.: Dealing with catchment heterogeneity in watershed hydrology: A review of recent progress towards new hydrological theory, Geogr. Compass, 3, 375-392, 2008.

Tromp-van Meerveld, H. J., and McDonnell, J. J.: Comment to "Spatial correlation of soil moisture in small catchments and its relationship to dominant spatial hydrological processes, Journal of Hydrology 286: 113-134”, J. Hydrol., 303, 307-312, doi:10.1016/j.jhydrol.2004.09.002, 2005.

Tromp-van Meerveld, H. J., and McDonnell, J. J.: Threshold relations in subsurface stormflow: 2. The fill and spill hypothesis, Water Resour. Res., 42, W02411, doi:10.1029/2004wr003800, 2006a.

Tromp-van Meerveld, H. J. and McDonnell, J. J.: Threshold relations in subsurface stormflow: 1. A 147-storm analysis of the Panola hillslope, Water Resour. Res., 42, W02410, doi:10.1029/2004wr003778, 2006b.

Unland, N. P., Cartwright, I., Andersen, M. S., Rau, G. C., Reed, J., Gilfedder, B. S., Atkinson, A. P., and Hofmann, H.: Investigating the spatio-temporal variability in groundwater and surface water interactions: a multi-technique approach, Hydrol. Earth Syst. Sci., 17, 3437-3453, doi:10.5194/hess-17-3437-2013, 2013.

Vidon, P. G. F. and Hill, A. R.: Landscape controls on the hydrology of stream riparian zones, J. Hydrol., 292, 210-228, doi:10.1016/j.jhydrol.2004.01.005, 2004.

Warmerdam, P. and Stricker, H.: Fundamental hydrological research results drawn from studies in small catchments, in: Status and Perspectives of Hydrology in Small Basins, IAHS Publ., Proceedings of the Workshop, 30 March-2 April 2009, GoslarHahnenklee, Germany, 47-53, 2009.

Western, A. W., Bloschl, G., and Grayson, R. B.: Geostatistical characterisation of soil moisture patterns in the Tarrawarra a catchment, J. Hydrol., 205, 20-37, doi:10.1016/s00221694(97)00142-x, 1998.

Western, A. W., Grayson, R. B., and Bloschl, G.: Scaling of soil moisture: A hydrologic perspective, Annu. Rev. Earth Planet. Sci., 30, 149-180, 2002.

Wilson, D. J., Western, A. W., Grayson, R. B., Berg, A. A., Lear, M. S., Rodell, M., Famiglietti, J. S., Woods, R. A., and McMahon, T. A.: Spatial distribution of soil moisture over 6 and $30 \mathrm{~cm}$ depth, Mahurangi river catchment, New Zealand, J. Hydrol., 276, 254274, doi:10.1016/s0022-1694(03)00060-x, 2003.

Wilson, D. J., Western, A. W., and Grayson, R. B.: Identifying and quantifying sources of variability in temporal and spatial soil moisture observations, Water Resour. Res., 40, W02507, doi:10.1029/2003wr002306, 2004.

Winter, T. C., Buso, D. C., Shattuck, P. C., Harte, P. T., Vroblesky, D. A., and Goode, D. J.: The effect of terrace geology on groundwater movement and on the interaction of ground water and surface water on a mountainside near Mirror Lake, New Hampshire, USA, Hydrol. Process., 22, 21-32, doi:10.1002/hyp.6593, 2008.

Wood, E. F., Lettenmaier, D. P., and Zartarian, V. G.: A land-surface hydrology parameterization with subgrid variability for generalcirculation models, J. Geophys. Res.-Atmos., 97, 2717-2728, 1992.

Woods, R. A. and Rowe, L.: The changing spatial variability of subsurface flow across a hillside, J. Hydrol., 35, 51-86, 1996. 
Woods, R. A., Grayson, R. B., Western, A. W., Duncan, M. J., Wilson, D. J., Young, R. I., Ibbitt, R. P., Henderson, R. D., and McMahon, T. A.: Experimental Design and Initial Results from the Mahurangi River Variability Experiment: MARVEX., in: Observations and Modelling of Land Surface Hydrological Processes, edited by: Lakshmi, V., Albertson, J. D., and Schaake, J., Water Resources Monographs, American Geophysical Union, Washington, D.C., 201-213, 2001.
Zimmer, M. A., Bailey, S. W., McGuire, K. J., and Bullen, T. D.: Fine scale variations of surface water chemistry in an ephemeral to perennial drainage network, Hydrol. Process., 27, 3438-3451, doi:10.1002/hyp.9449, 2012. 